\title{
دور الجمعية العامة للأمم المتحدة في مكافحة العنف ضد المرأة وقت السلم
}

The role of the United Nations General Assembly in combating violence against women in peacetime

\author{
تاريخ الاستلام : 2019/10/17 ؛ تاريخ القبول : 2020/04/04
}

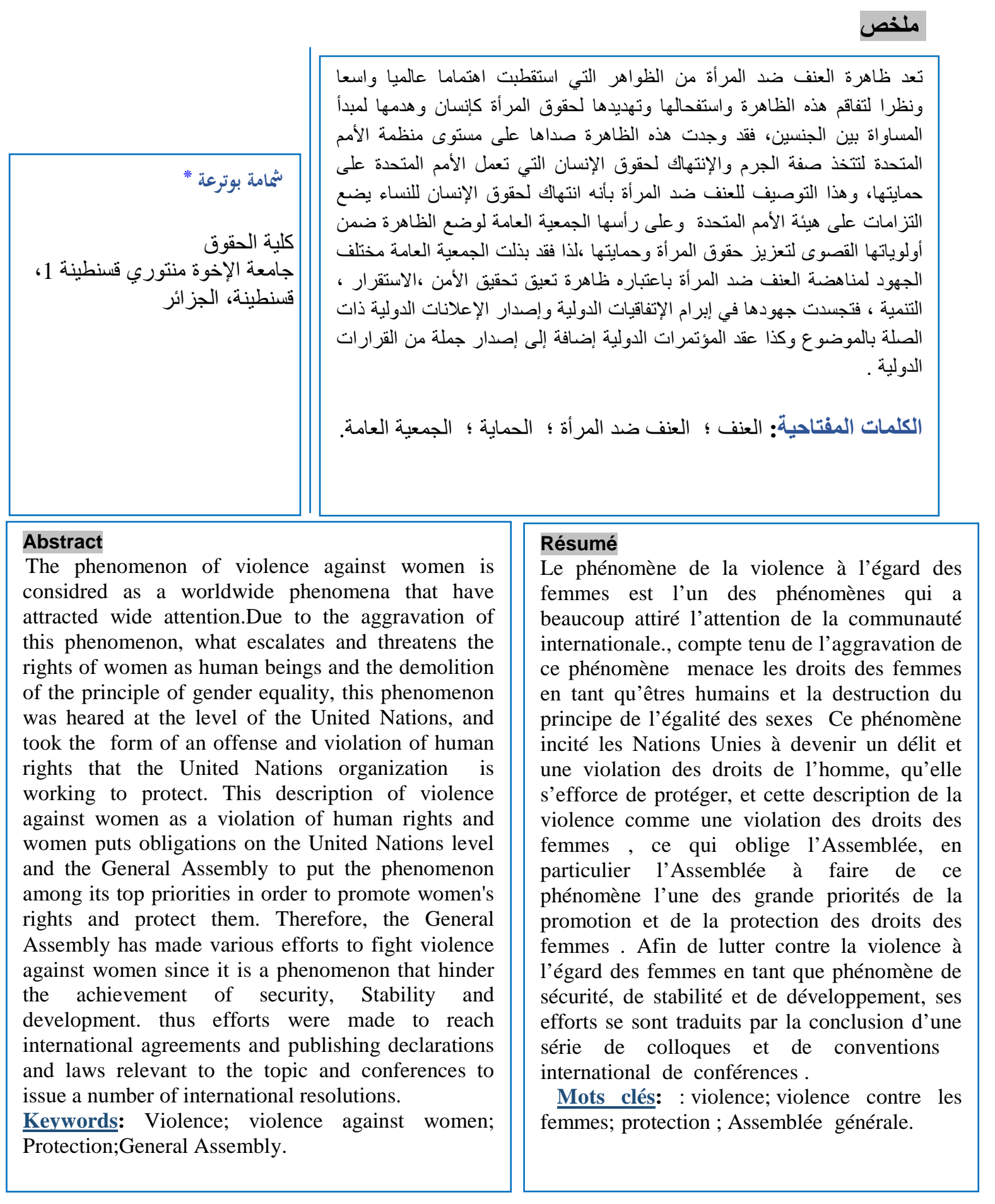

* Corresponding author, e-mail: chemama.bouteraa@gmail.com

(C) جامعة الاخوة منتوري قسنطينة 1، الجزائر 2020. 


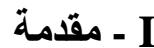

يمثل الإنسان غاية كل النظم الدولية، وما وجدت هذه النظم إلا من أجل الإنسان

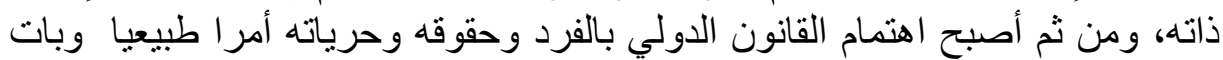

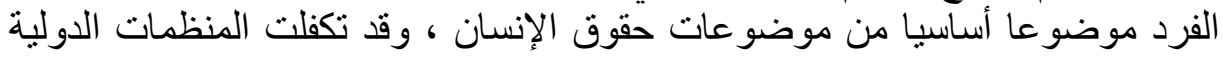

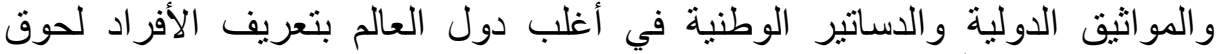

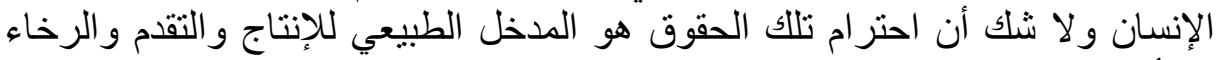

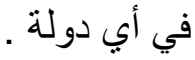

ولما كانت المرأة إنسانا ،فهي الأخرى تحظى بالإهنمام وحماية حقوقها استنادا لمبدا المساو اة بين الجنسين ، الذي بعد أهم مبادئ حوق الإنسان الإنسان.

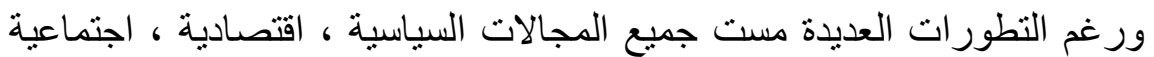

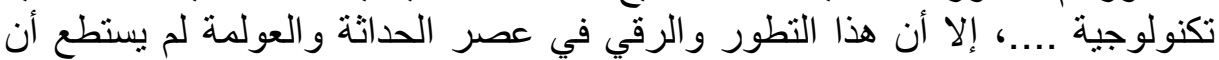

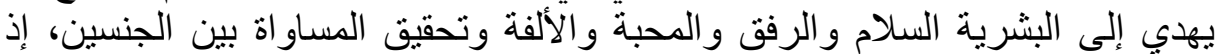

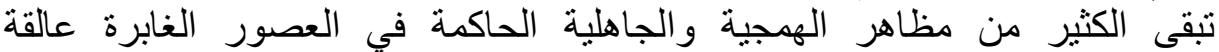
ومترسخة في النفس البشرية وكأنها تأبى الزوال الجال .

وظاهرة العنف عامة هي من هذا النوع الذي يحمل هذا الطابع إذ أنها تهدا لإنها

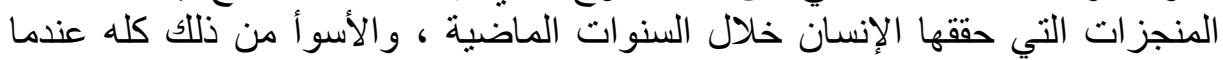

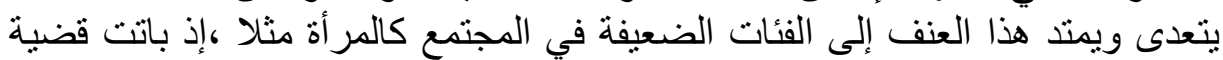

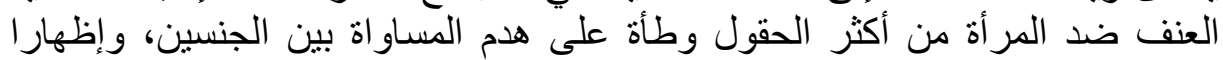
للاونية في معاملة المرأة ـ العند أكنر

ويعد العنف الموجه ضد المر أة من أبرز المشكلات العالمية التي لا يكاد يخلو منها

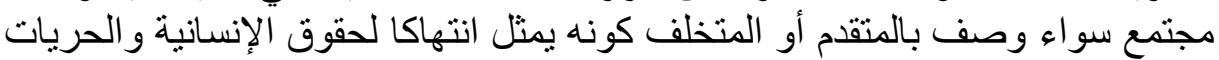

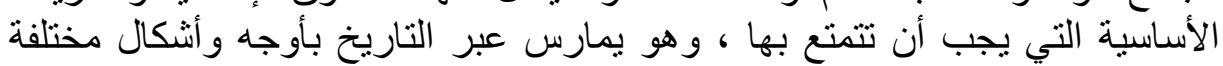

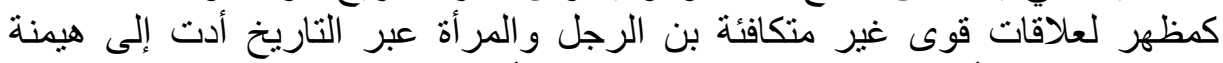

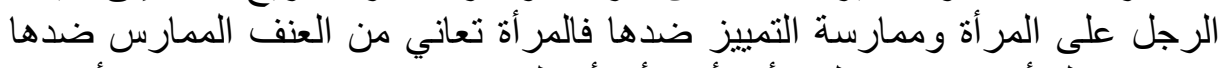

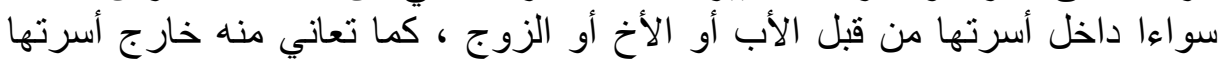

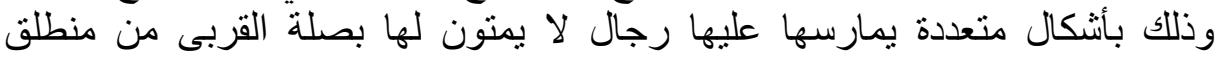

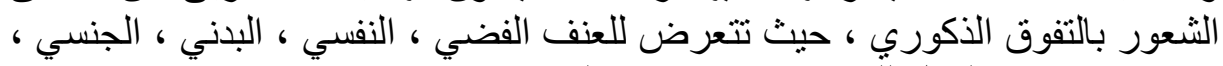

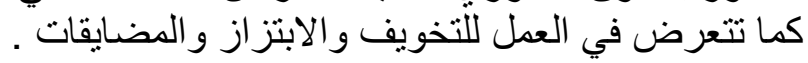

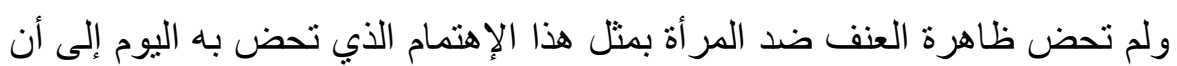

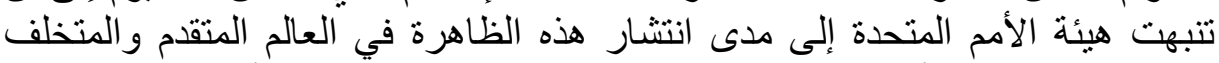

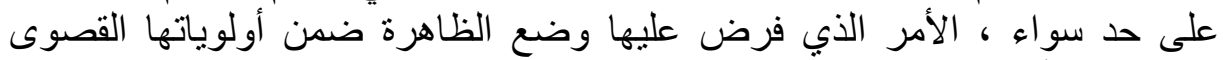

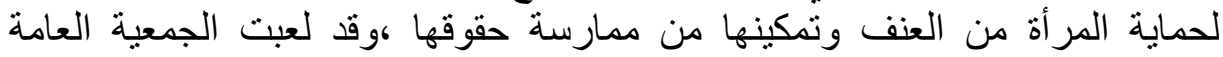

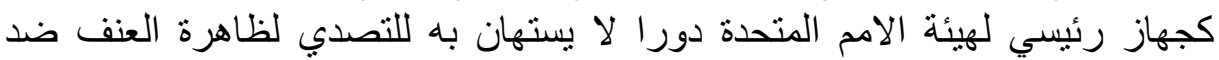

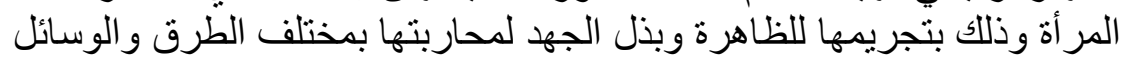

وتكمن أهمية الموضوع في أن العنف ضد المرأة بجميع أنواعه وأشكاله أصبح

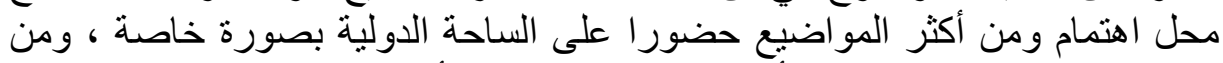

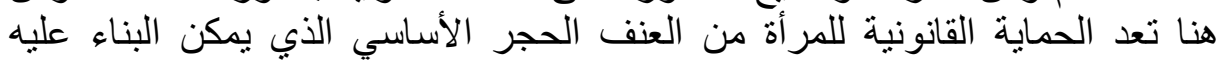

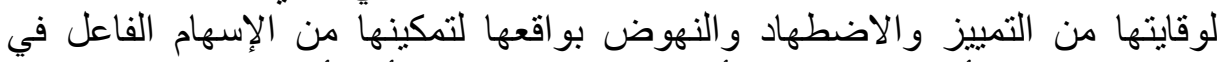

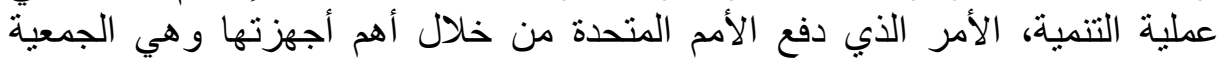

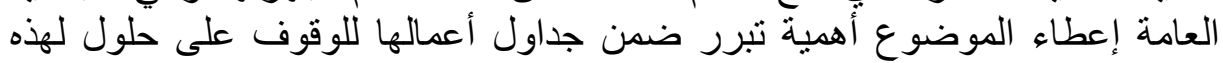

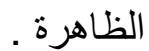


ومما لا شك فيه أن أي بحث مهما كان نو عه لابد أن ترسم له أهداف يسعى الباحث

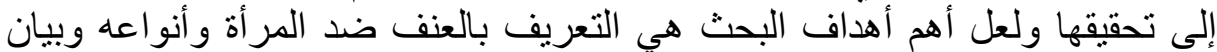

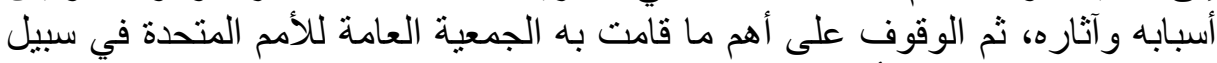

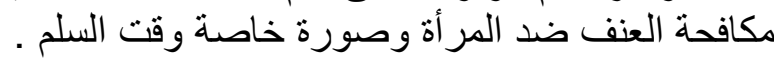
وقد تم الإعتماد في هذا البحث على المنهج الوصفي و المنهج التحليلي .

إذا أمام استفحال ظاهرة العنف ضد المر أة، وأمام أخذ الجمعية العامة للأمم المتحدة

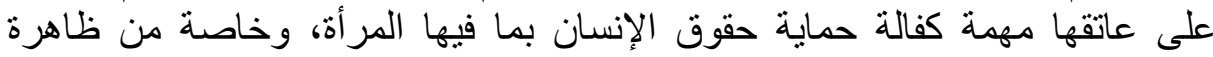

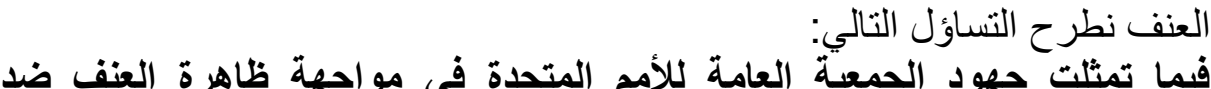

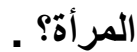

وإجابة على التساؤل المطروح ارتأينا إلى تقسيم البحث إلى محورين أساسيين

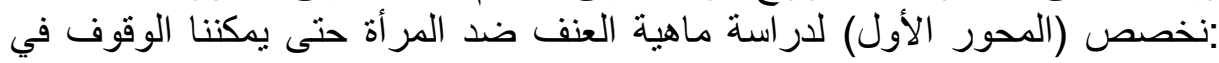
(المحور الثاني) على الجهود المبذولة من قبل الجمعية العامة لمواجهة الظاهرة .

\section{المحور الأول : ماهية العنف ضد المرأة}

تستقطب ظاهرة العنف ضد المرأة اهتماما عالميا ،وقد بدا ذلك جليا من خلال المواثيق

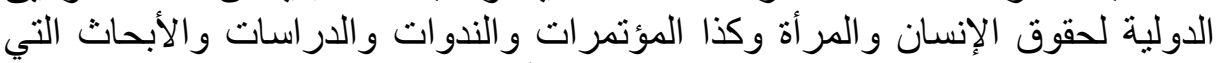

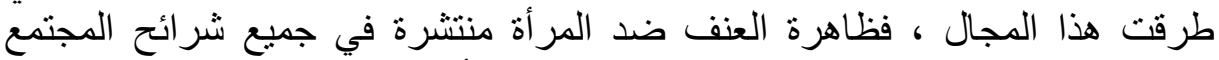

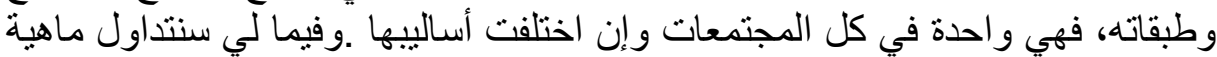

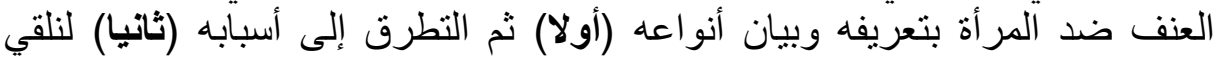

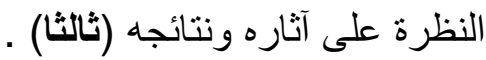
أولا : تعريف العنف ضد المرأة وأنواعه :

للعنف عدة تعاريف ومفاهيم تختلف باختلاف السياق الذي ينظر إليه منه، ومن حيث

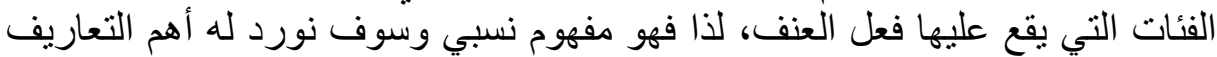

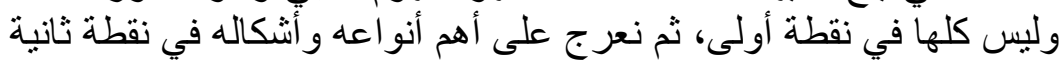

\section{1- 1 - تعريف العنف:}

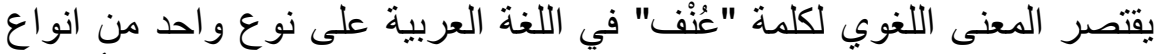

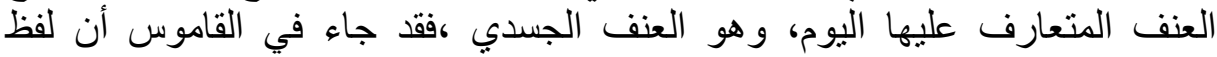
"عُنْ" مشتقة من مادة عنف ويقال عنف به و عليه أب أخذه بثدة وقسوة فهو عنيف(1) وقد جاء في القاموس الفرنسي أن العنف تعبير يعود إلى سنة 1215 ويعني الاستخدام المتصف للقوة واستخدام العنف هو العمل الموجه ضد خصم لإرغامه على إنى القيام بعمل ضد إر ادته باستخدام القوة و التخويف (2)". أما في اللغة الإنجليزية فقد حدد قاموس ويبستر(1979. webster )سبقه معان على

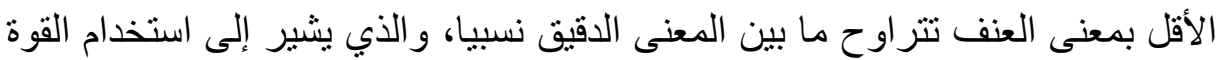

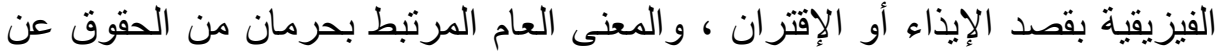

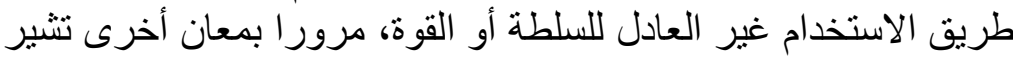
جميعها إلى الهجوم والعدوان واستخدام الطاقة الجسدية ورفض الآخرين بصورة 


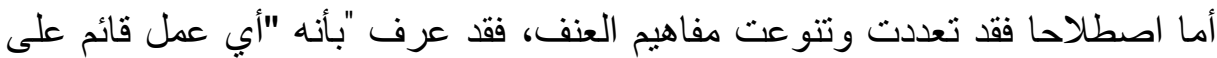

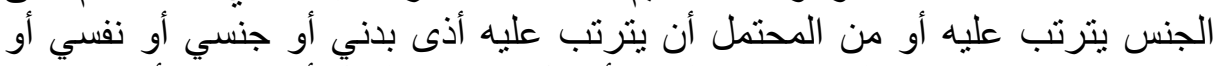
معاناة للشخص بما في ذلك التهديد بالقيام بأعمال من هذا التهن القبيلّ أو الإكراه أو الح الحرمان

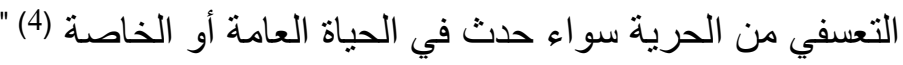
كما عرف أيضا أنه " السلوك أو الفعل الموجه إلى المرأة على وجه الخصوص سواء

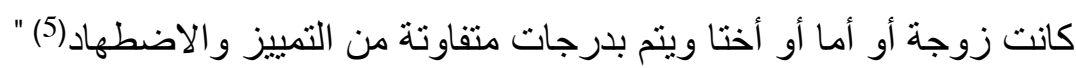

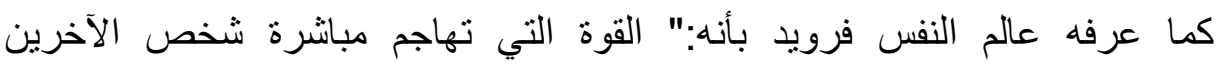

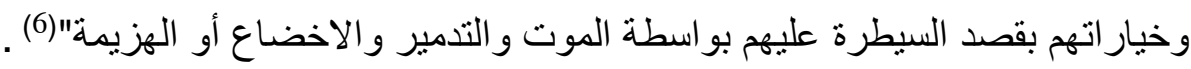

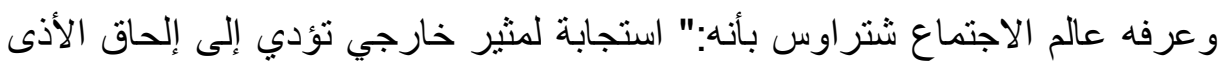

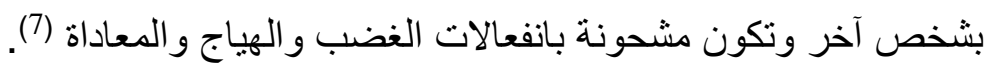

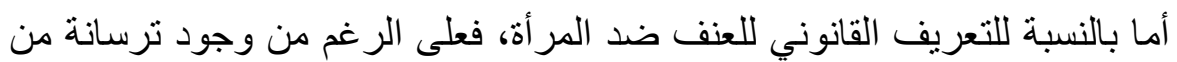

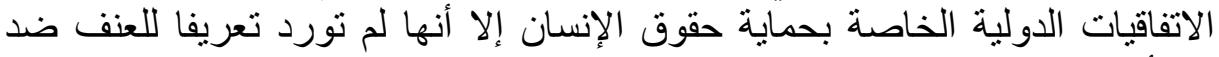

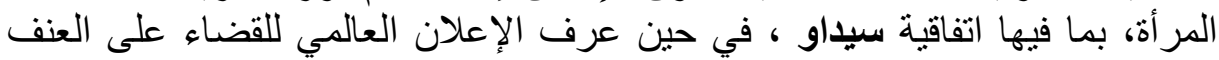

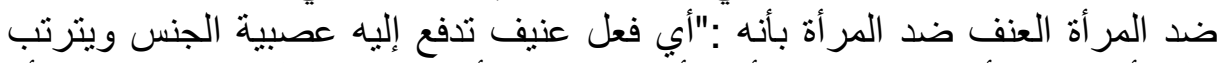

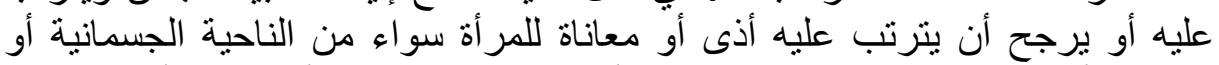

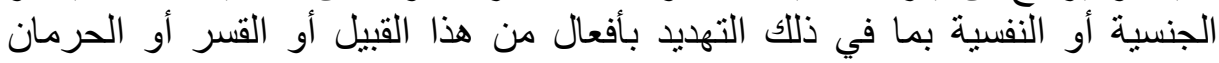

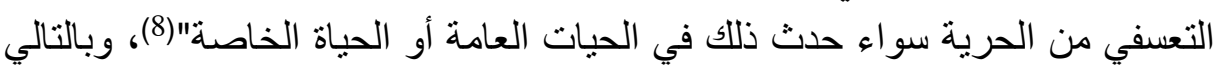
كان هذا الإعلان أول وثيقة دولية يتم من خلالها تعريف العنف ضد المرأة بصورة

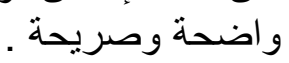

كما عرفت الاتفاقية الأمريكية بشأن منع واستنئصال العنف ضد النساء والعقاب

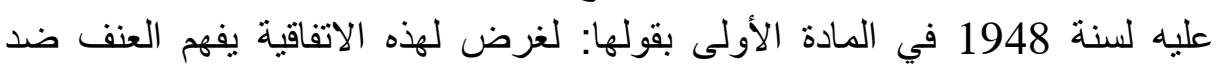

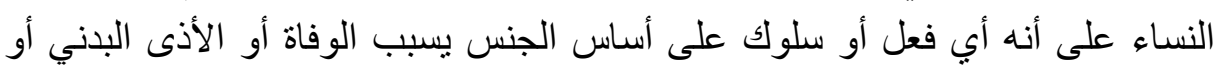

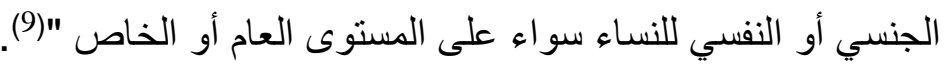

\section{2-أنواع العنف ضد المرأة: 2 - 2}

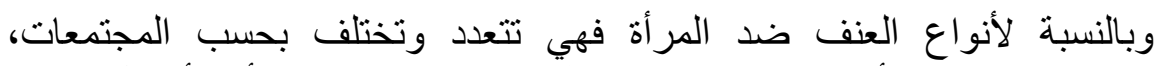
فالظاهرة واحدة ولكن أساليبها متنوعة ومختلفة وسنذكر فيما يلي أهم أنشكال العنف

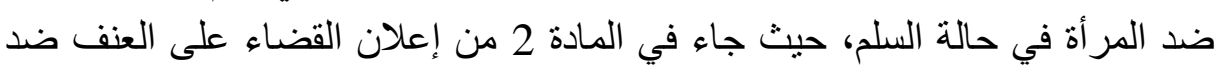

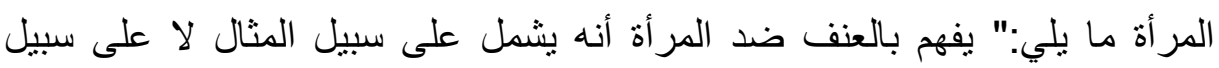

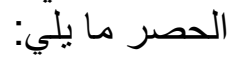

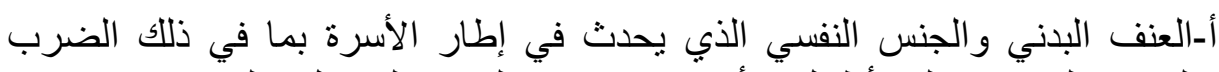

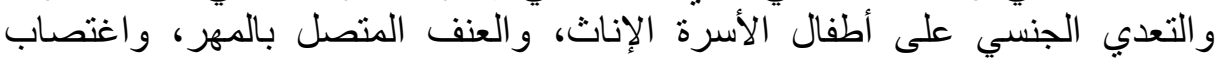

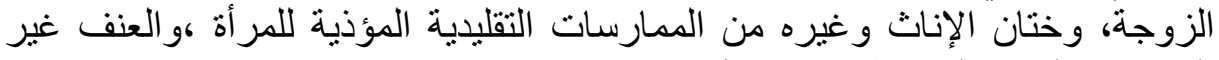

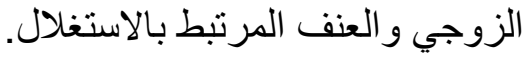

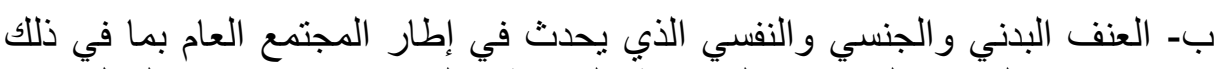
الاغتصاب والتعدي الجنسي والمضايقة الجنسية والتخويف في مكان العمل وفي العي 
المؤسسات التعليمية و أبي مكان آخر، و الإتجار بالنساء و إجبار هن على البغاء.

ج-العنف المدني و الجنسي و النفسي الذي ترنبكه الدولة أو تتغاضى عنه أينما وقع".

باستقر اء هاته المادة يمكن القول أن هناك ثناث أنواع رئيسية للعنف ذكرتها المادة 2

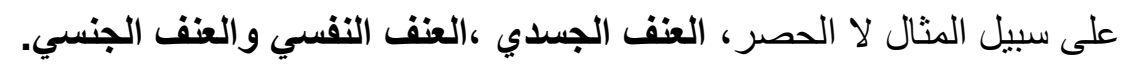

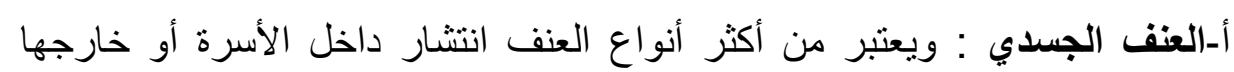

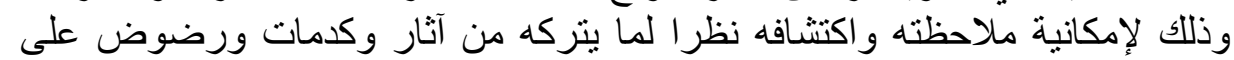

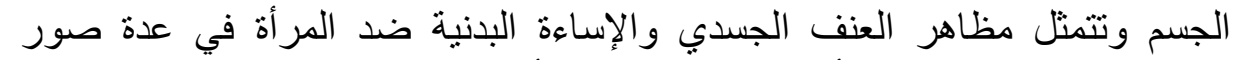

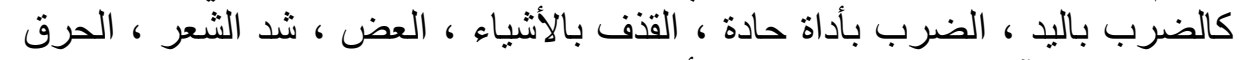

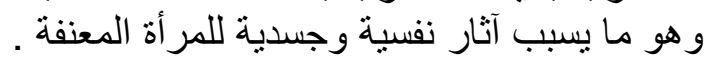

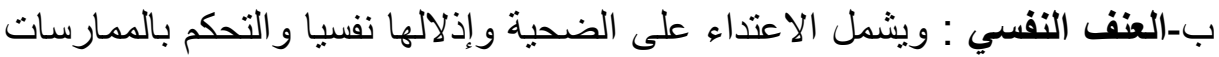

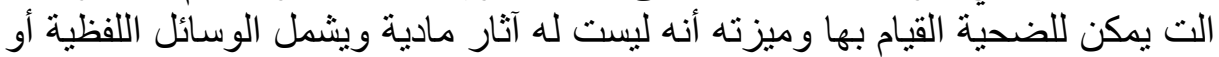

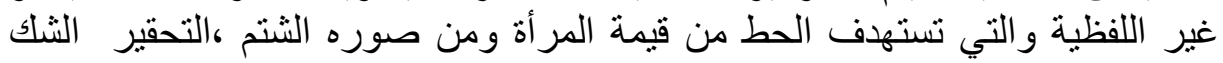
وسوء الضن ، التهديد لزعز عة عنة النقة.

ج-العنف الجنسي : وهو أي وضع يتم فيه استخدام التهديد أو القوة من أجل الحصول

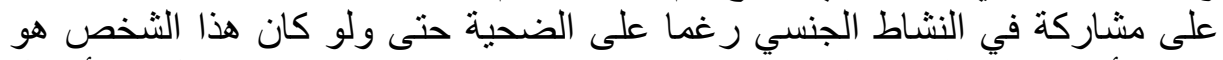

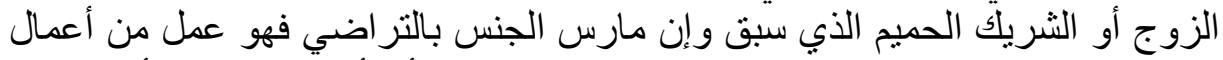

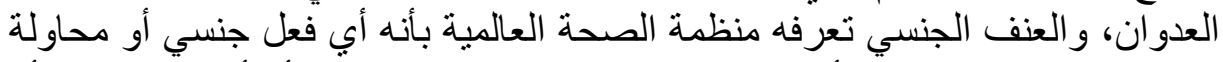

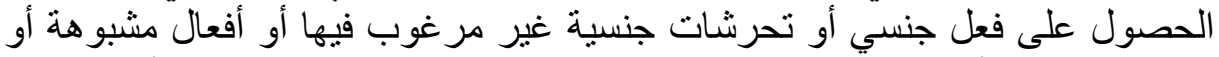

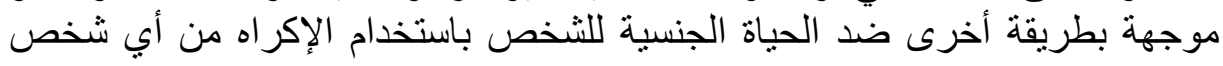
بغض النظر عن علاقته بالضحية في أي مكان (10).

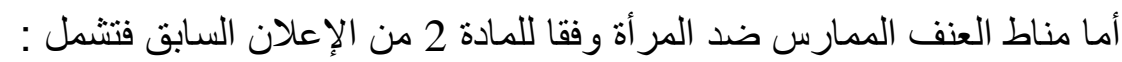
أـالعنف الأسري: هو أحد أنماط السلوك العدواني "الذي ينتج عن وجود علاقات قوة

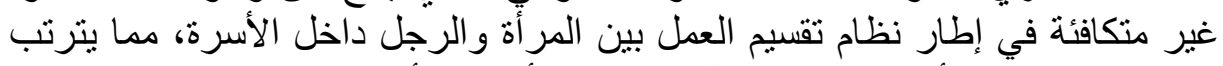

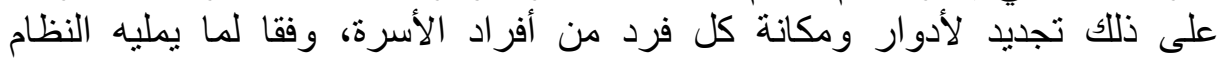

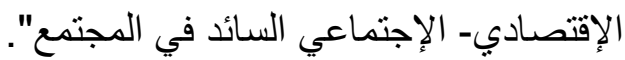

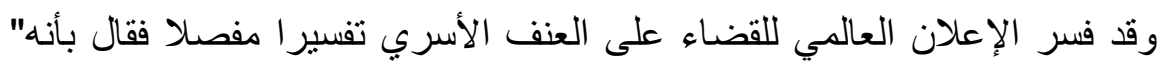

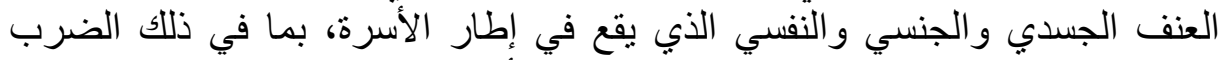

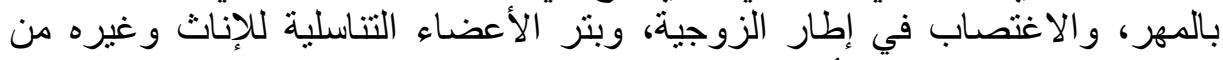

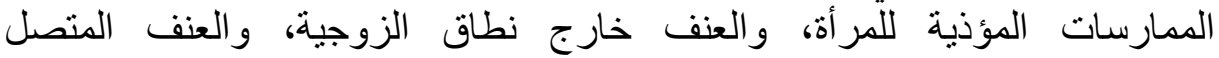
بالاستغلال".

كما يثمل أيضا عملية الإنجاب المتواصل وعدم تحديد النسل وارتفاع معدل الإنجاب(11)

ب-العنف المجتمعي : ويعني حرمان المرأة من ممارسة حقوقها الإجتماعية

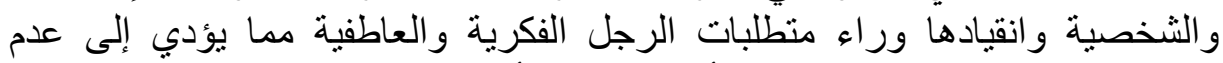

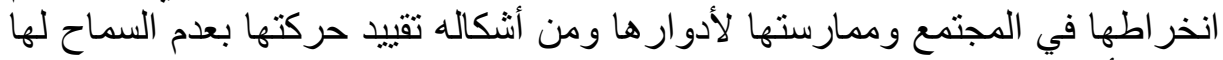

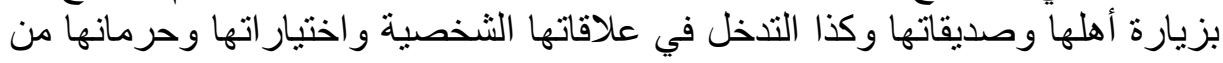

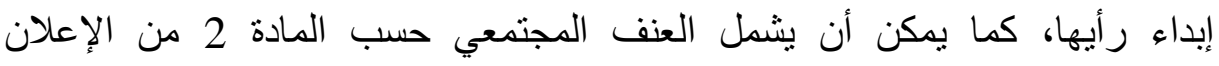
الاغتصاب والتعدي الجنسي والمضايقة الجنسية والتخويف في مكان العمل وفي لئي 
المؤسسات التعليمية و أبي مكان آخر، و الإتجار بالنساء و إجبار هن على البغاء.

ج- العنف القانوني: يشمل العنف القانوني العنف المدني والجنسي والنفسي الذي ولئي

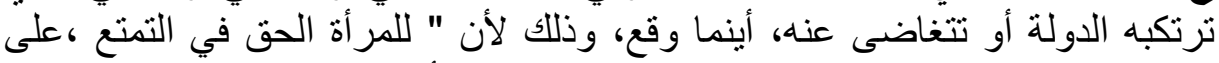

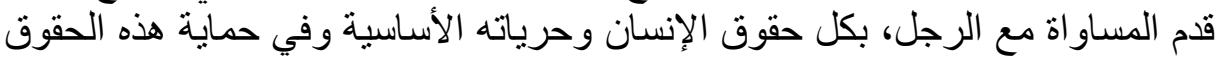

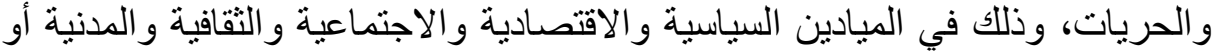

أبي ميدان آخر و

ثانيا : أسباب العنف ضد المرأة

تتعدد أسباب العنف ضد المرأة وتتنوع من مجتمع إلى آخر إلا أنه غالبا ما يكون لئه

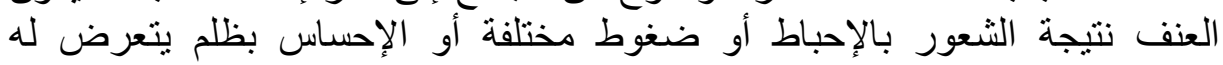

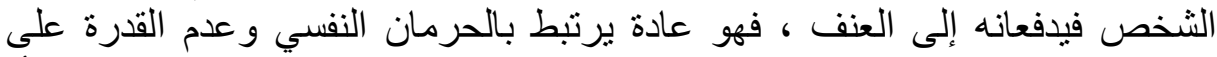

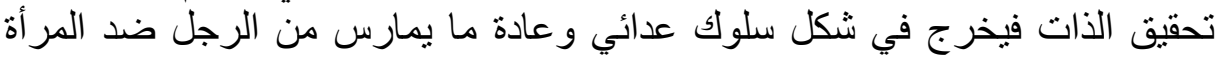
ومن أهم العو امل المؤدية للعنف عموما ما يلّي :

1-العوامل الإقتصادية : إذ يعتبر الفقر والبطالة وخاصة بطالة رب الأسرة من أهم

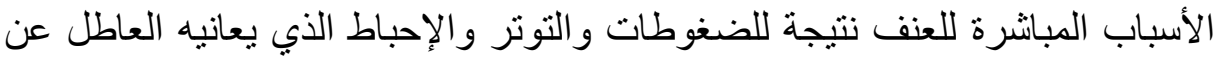

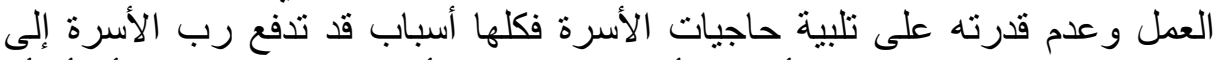

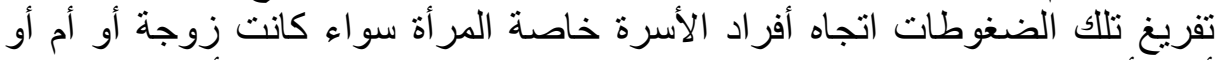
أخت أو ابنة فتتعدد بذلك صور العنف الممارس ضده الفها فقد يكون مادي أو معنوي .

2-العوامل الإجتماعية والثقافية: كعدم التكيف أو التأقلم بين الجنسين وعدم المساواة

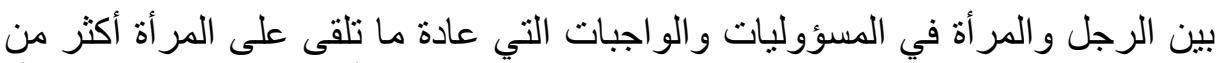

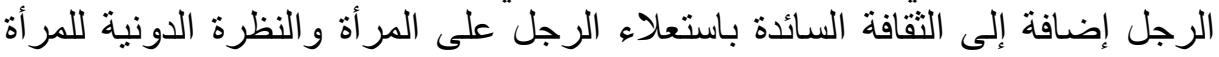

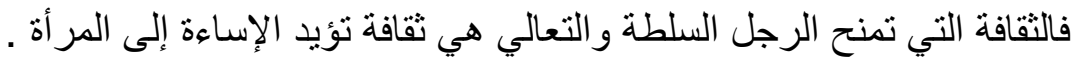

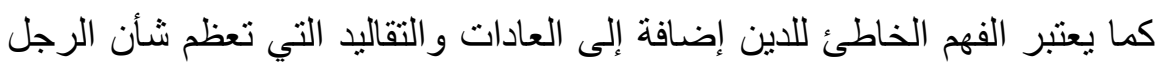

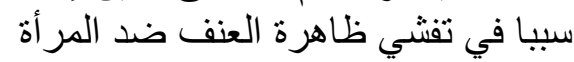

كما يسبب تقاعس الدولة بسلطاتها خاصة التشريعية حين تمتتع عن سن تشريعات

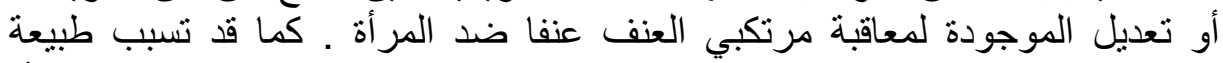

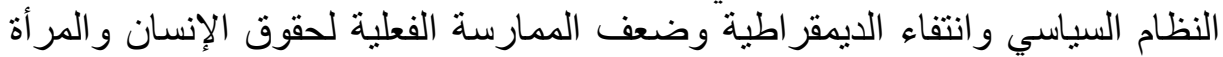
سببا في تعنيف المرأة النغاء

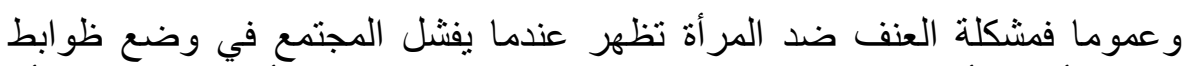

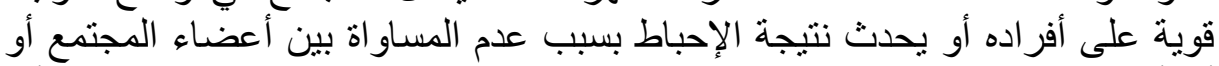

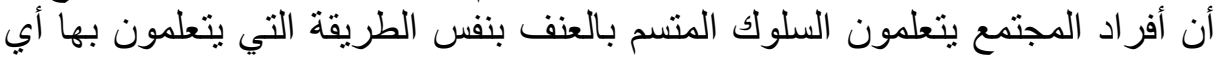

نمط آخر من السلوك(12)

ثالثا : آثار العنف ضد المرأة :

بما أن العنف مشكلة متعددة الأوجه فهو مشكلة اقتصادية ، اجتماعية ، ثقافية في

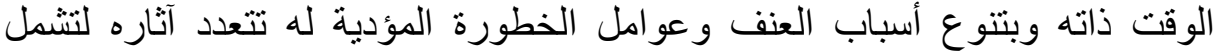

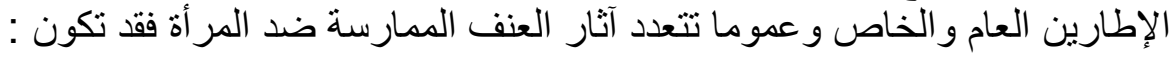
1- آثار نفسية : حيث غالبا ما ينتج عن العنف ضد المرأة امرأة معنفة تفقد ثقتها بنفسها واحترامها لذاتها، فهي تشعر دائما بالنقص فتعيش معزولة فئة عن الحياة 
الإجتماعبة كما تصاب باضطر ابات نفسية و اضمحلال في الثخصية مما يقودها إلى تلى

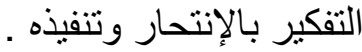

2- الآثار الجسدية : فقد ينتج العنف ضد المرأة آثار مادية ملموسة مثل الكسور

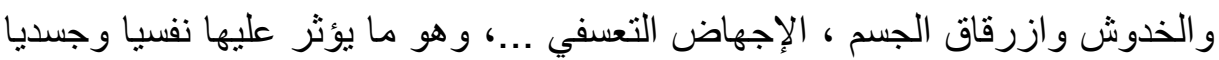
وكذلك نتيجة للألم الجسدي والنفسي و الثُعور بالإحباط قد تلجأ المر أة إلى الإدمان على التى

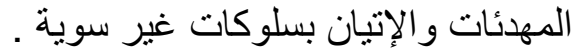

3- الآثار الإجتماعية : وتعتبر هذه الآثار من أثد ما يتركه العنف على المرأة

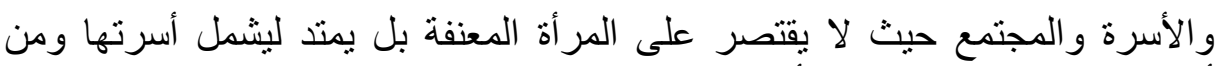
أبرز آثاره الطلاق والتفكلك الأسري .

4- الآثار الإقتصادية: من نتائج انتشار العنف ضد المرأة إعاقة متطلبات التنمية الإقتصادية بسبب عدم تمكن المرأة المعنفة من الإندماج في سوق العادئه العمل وزيادة التكلفة الإقتصادية لمعالجتها . الإن

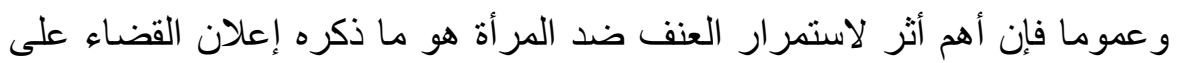

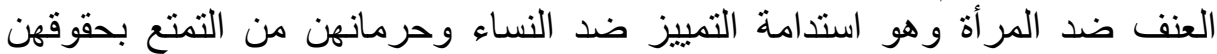

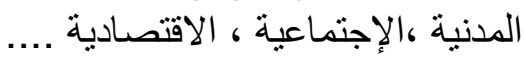

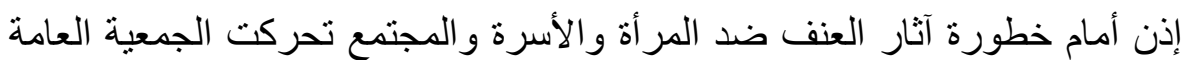

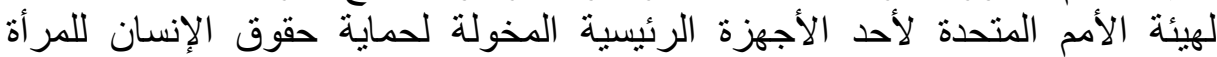

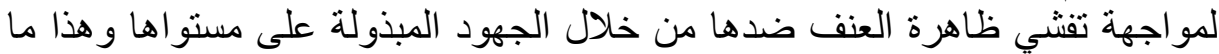

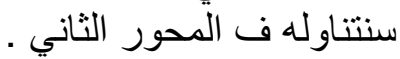
المحور الثاني : جهود الجمعية العامة لمكافحة ظاهرة العنف ضد المرأة وقت السلم

تعتبر الجمعية العامة أحد الأجهزة الرئيسية للأمم المتحدة التي تمثل فيها الدول

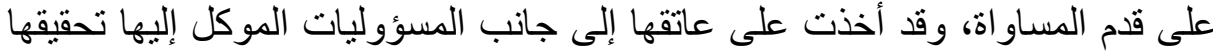

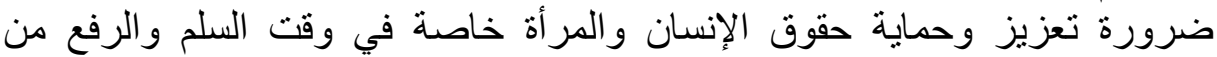
مكانتها وذللك بمناهضة العنف ضدها عن طريق جملة من الجهود المبذولة والتهان والتي

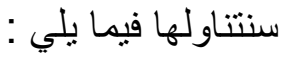

أولا : دور الجمعية العامة في إبرام الاتفاقيات الدولية وإصدار الإعلانات الدولية

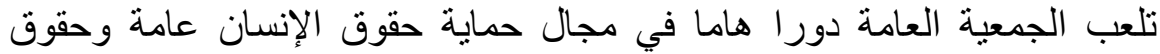

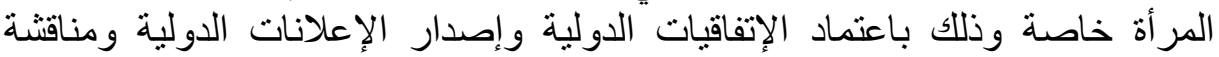

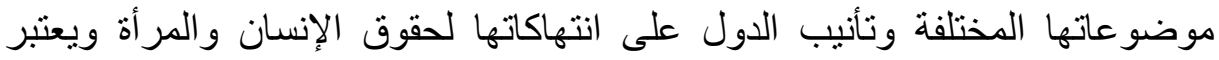
إصدار ها للإعلان العالمي لحقوق الإنسان عام 1948 والعهدين الدوليين عام 1966

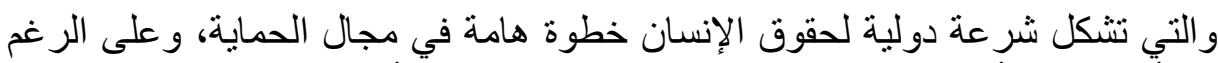

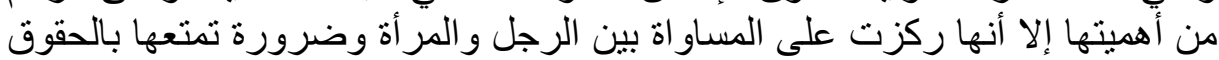

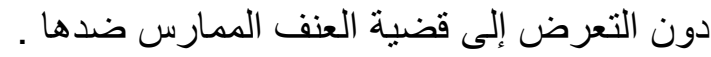

وبالنسبة لقضية العنف ضد المرأة فقد بدأت الجمعية العامة بالدعوة إلى مناهضة التمبيز ضدها، وكان ذلك بإصدار إعلان القضاء على التمييز ضد المر أة بقرارها الى رقم 2263 (د-22) المؤرخ في 07 نوفمبر 1967 وذلك لتحقيق المساواة بين الرجل 


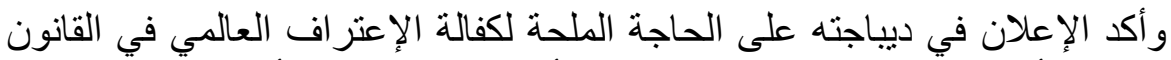

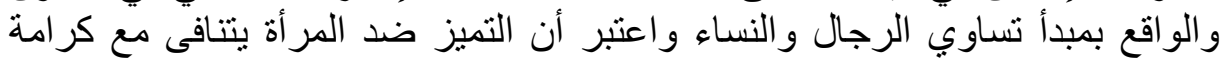

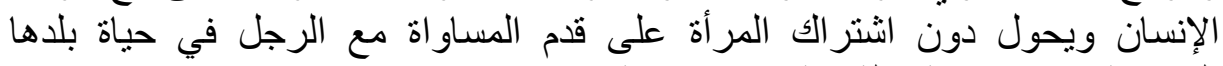

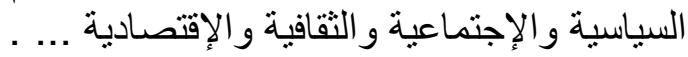

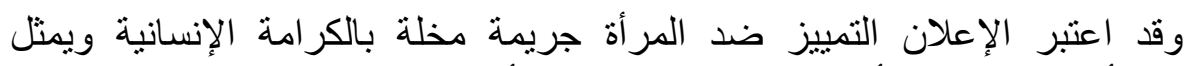

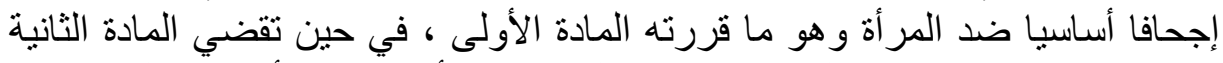

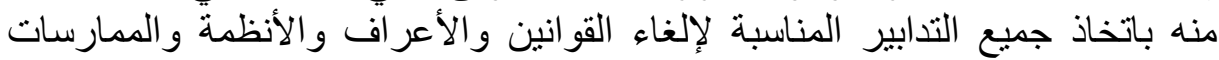

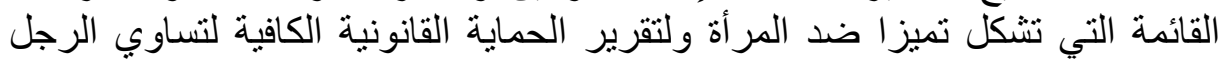

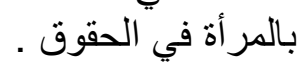

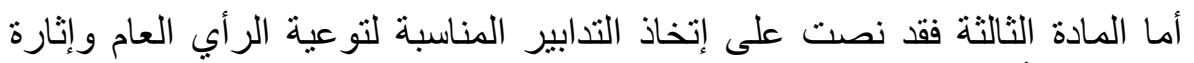

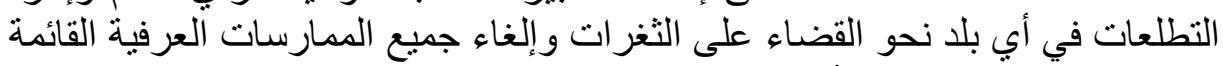

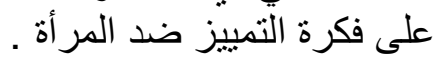

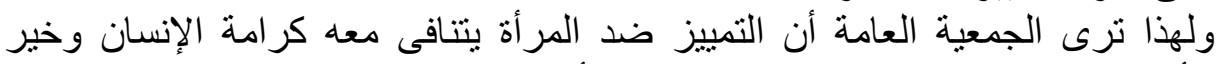

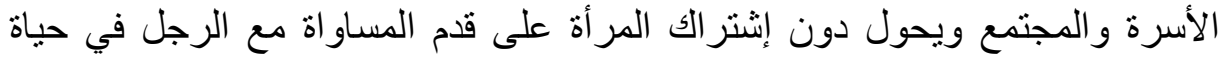

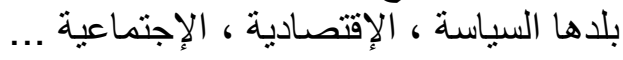

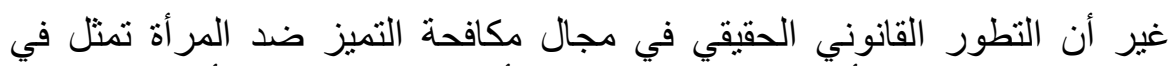
إتفاقية القضاء على كل أشكال التمييز ضد المرأة أنساء ( سيداو) و التي أقرتها الجمعية العامة للأمم المتحدة بقرارها رقم 180/34 المؤرخ في : 18 ديسمبر 1979 ودخلت 197 ودلت حيز التتفيذ في 03 ديسمبر 1981 (14).

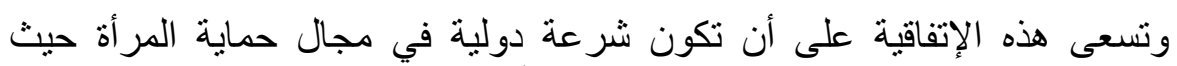

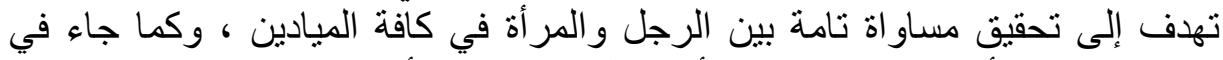

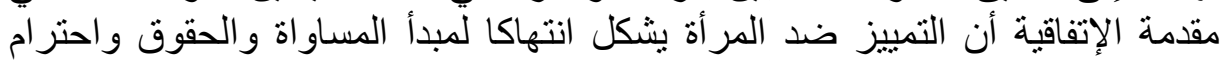

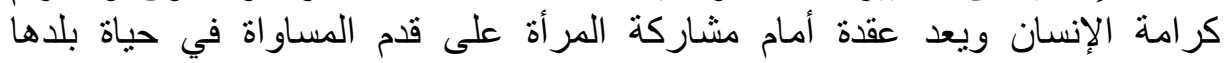
السياسية ، الإقتصادية الإن ودعة ع....

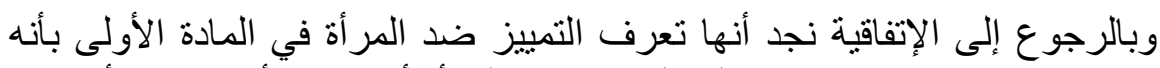

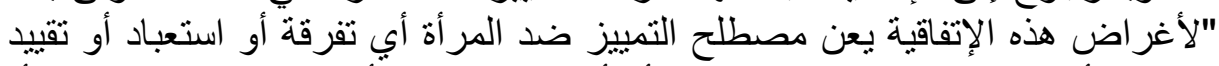

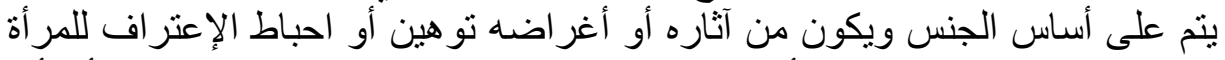

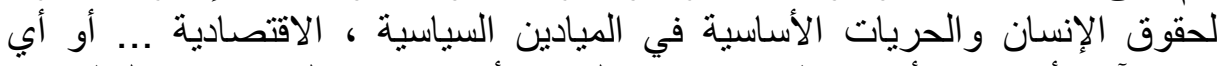

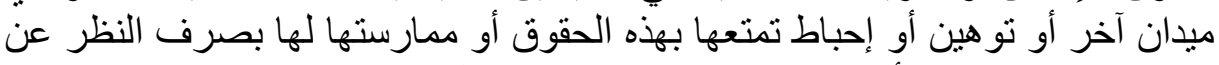

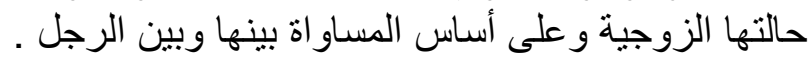

بينما تؤكد باقي مواد الإتفاقية وجوب أن تدمج الدول مبدأ المساواة بدساتير هاتيا

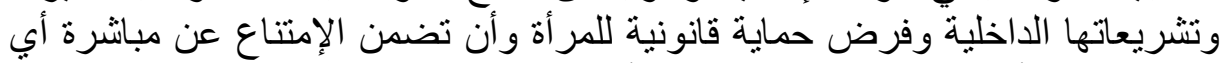

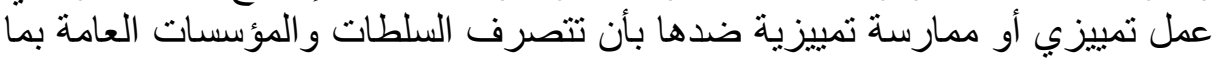

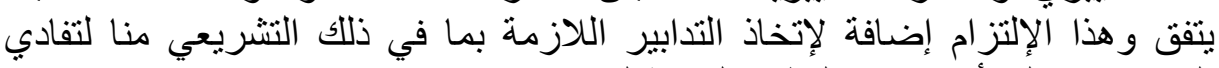

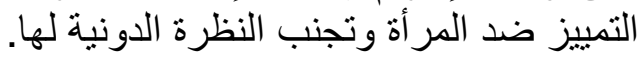

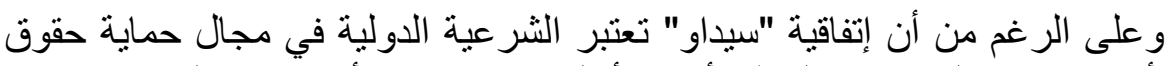

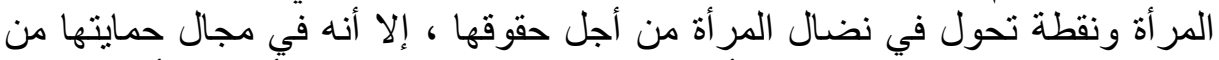

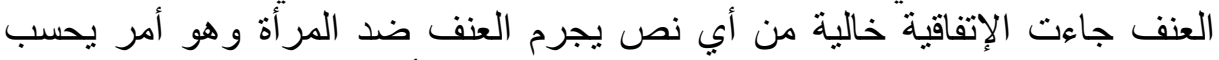

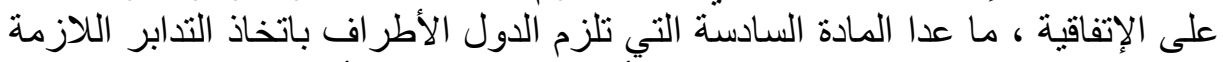

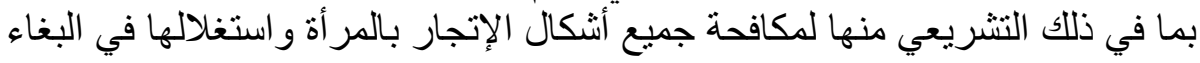


و تداركا للنقص الذي اعترى الاتفاقية فيما يخص العنف ضد المرأة أصدرت لجنة القضاء على التمييز ضد المرأة التوصية رقم 12 لسنة 1989 و التوصية رقم 19 لسنة 1992 بناء على سلطتها في تقديم توصيات عامة لمساعدة الدول على الوفاء

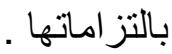

إن لجنة القضاء على جميع أشكال التمييز ضد المرأة، اعتبرت في توصيتها رقم

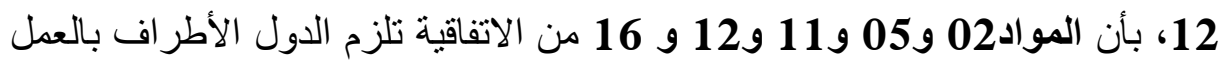

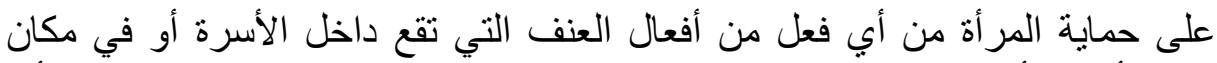

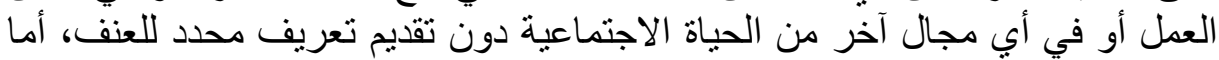

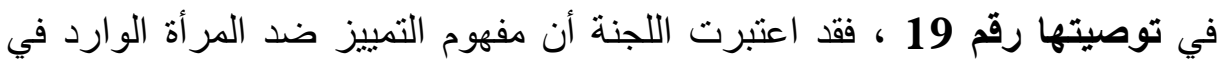

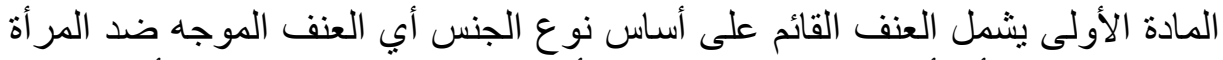

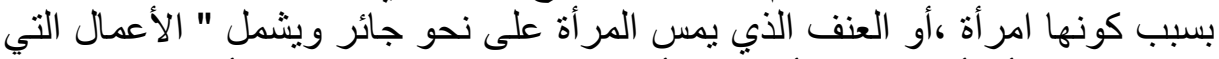

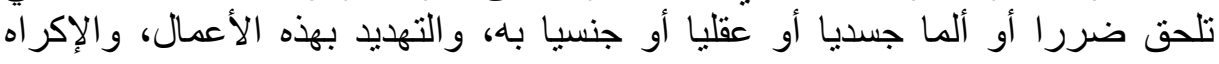
وسائر أثكال الحرمان من الحرية."(15)

وترى اللجنة أن العنف على أساس نوع الجنس الذي ينال من تمتع المرأة بحقوق

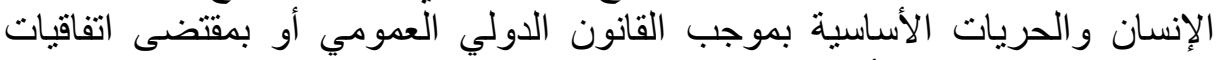

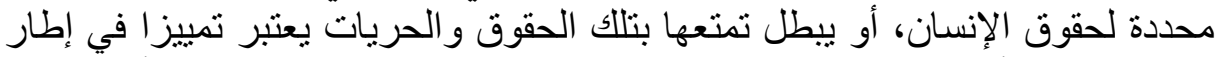

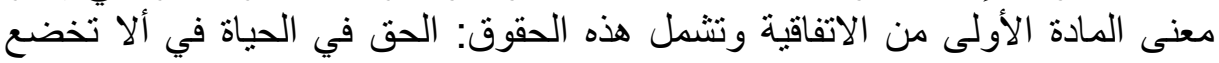

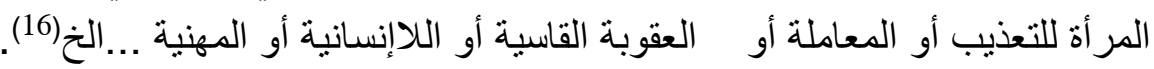

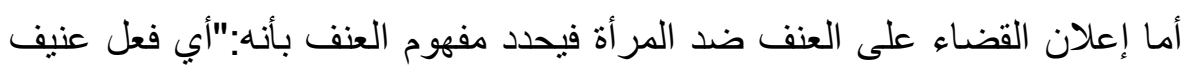

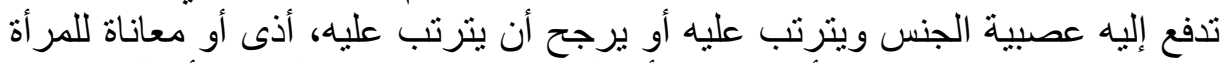

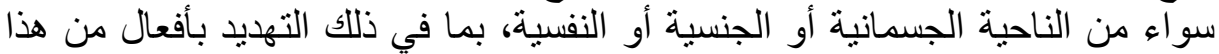
القبيل، أو القسر أو الحرمان التعسفي من الحرية سواء الجية حدث ذللك في الحياة العامة أو الو

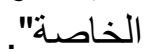

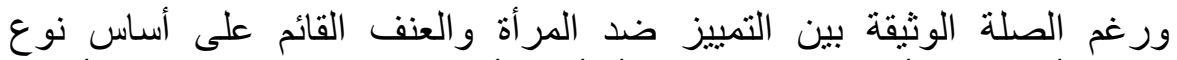

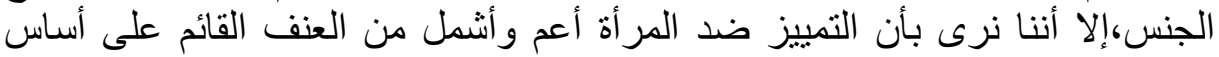

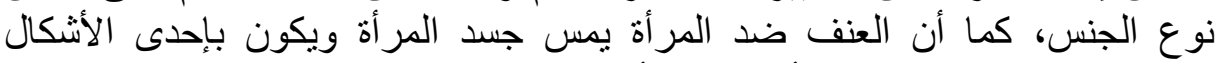

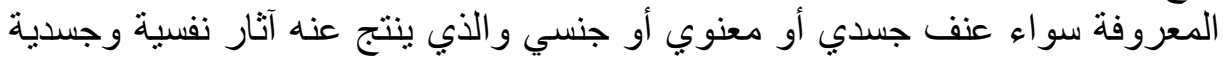

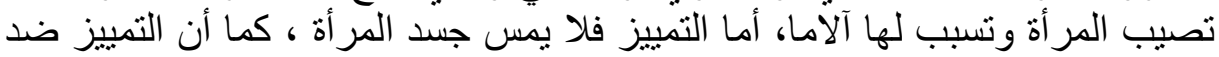

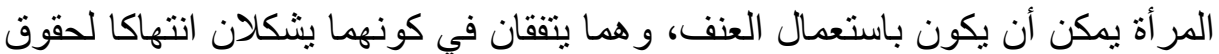

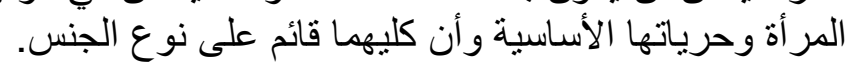

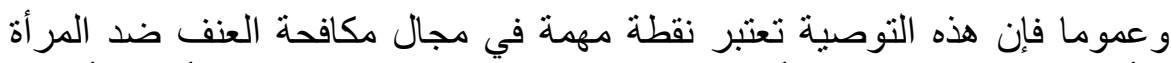

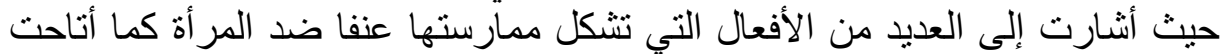

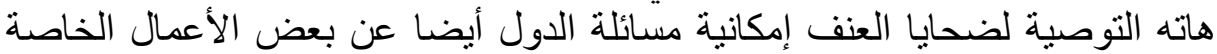

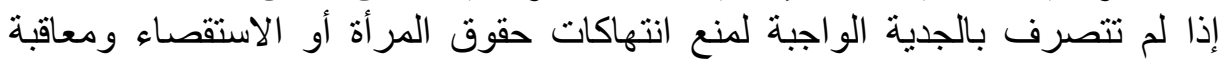
مرتكبي العنف وتقديم تعويض مناسب للنساء المعنفات (17).

و وأمام النقائص التي تضمنها إعلان وإتفاقية القضاء على التمييز ضد التد المرأة

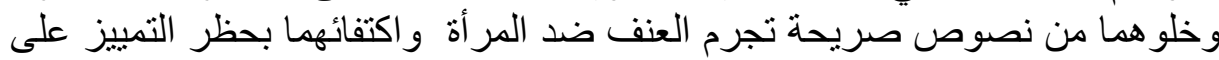

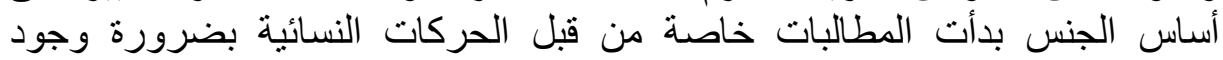
مو اثثق صريحة تجرم العنف ضد المرأة لذا فقد وضعت الجمعية العامة هاته المشكلة 
ضمن أولويات جداول أعمالها فأصدرت إعلان القضاء على العنف ضد المرأة بموجب قرارها رقم 104/48 المؤرخ في 1993/12/20 (18) وقد جاء هذا الإعلان نتيجة للافع الكبير الذي قدمه مؤتمر فيينا لحقوق الإنسان المنعقد عام 1993

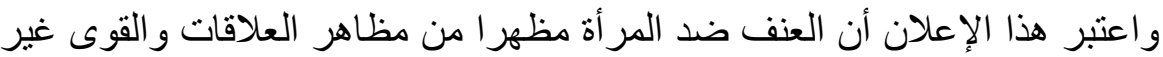

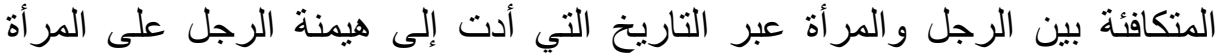

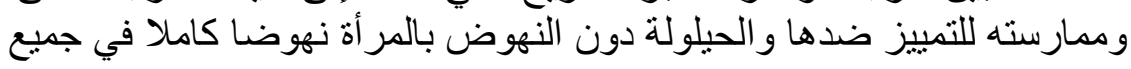

ميادين الحياة وأوضح أيضا أن العنف ضد المرأة يشكل انتهاكا لحوق الإنسان

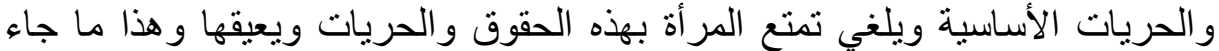
في ديباجة الإعلان الانيان

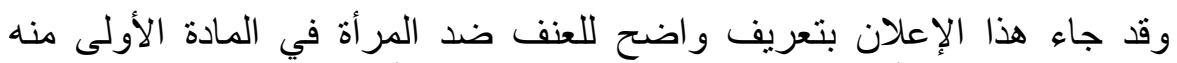

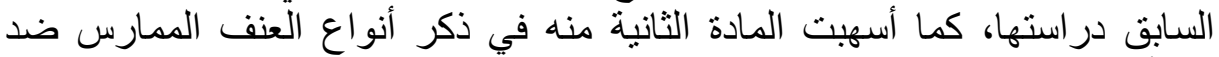

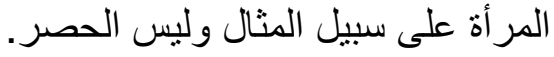

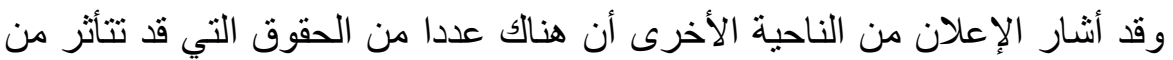

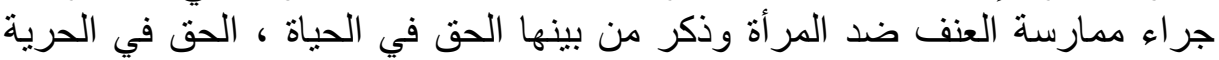

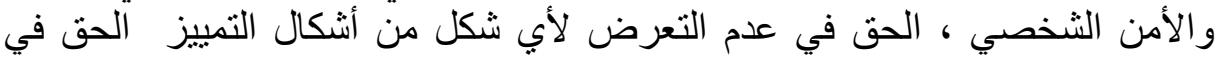

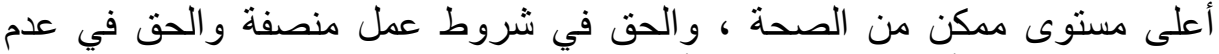
الخضوع للتعذيب أو المعاملة القاسية أو لا إنسانية .

و أكد الإعلان على وجوب أن تجتهد الدول الإجتهاد الواجب من أجل درأ أفعال

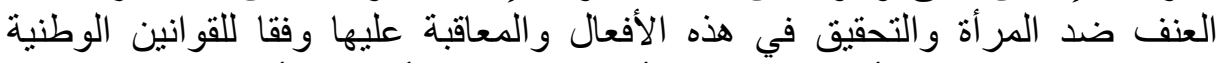

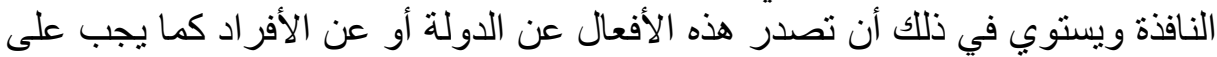

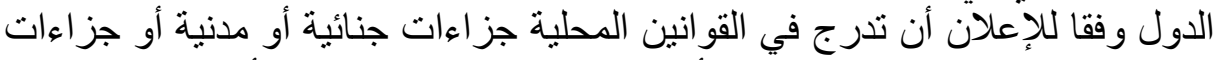

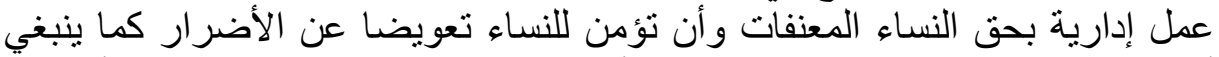

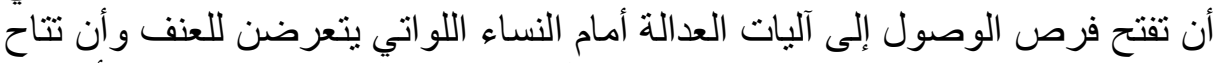

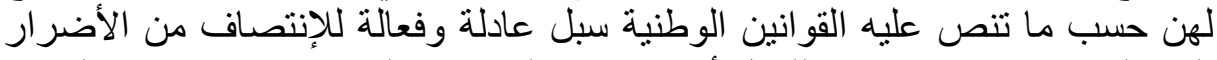

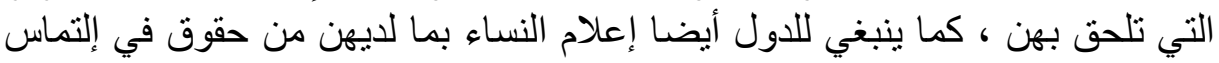

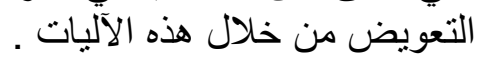

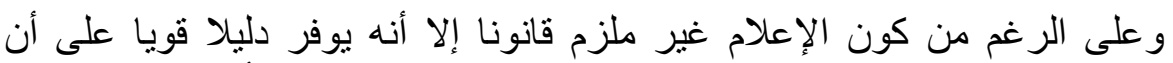

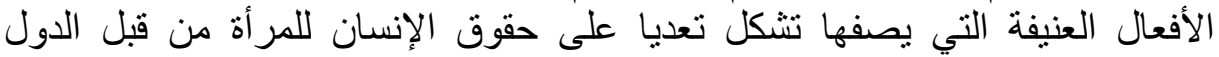

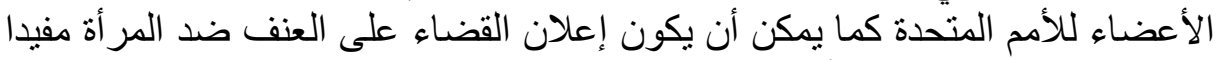

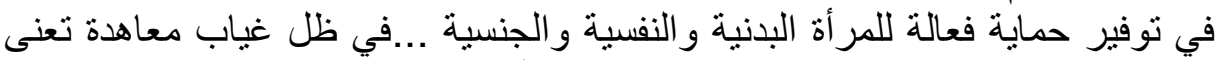

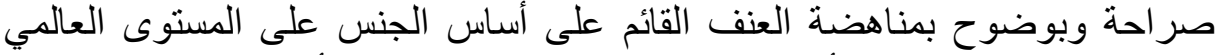
ولهذا فإن العنف ضد المرأة يقلق الجمعية العامة ويمثل عقبة أمامها لتحقيق المساواة العاة العائ و التنمية والسلم في ظل تفشي ظاهرة العنف ضد العندة المرأة في كل أقطار العالم

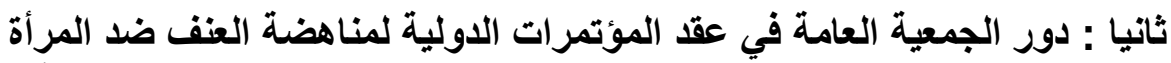

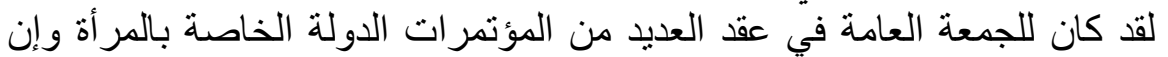

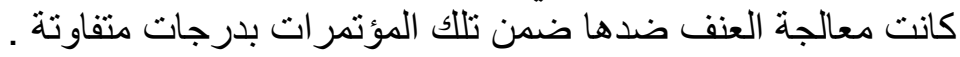


وقد كان عام 1975 عاما مميزا بالنسبة للمرأة حيث بدأ الإهتمام بهذه السنة قبل

ثلاث سنوات منها مع إعلان الجمعية العامة للأمم المتحدة في جلستها المنعقدة في 18

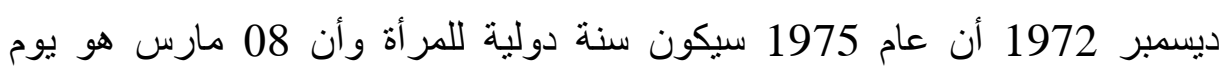
عالمي للمر أة وفي هذا العام عقد المؤتمر العالمي للمرأة في مدينة ميكسيكو سيتي من

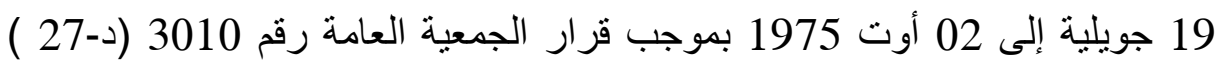

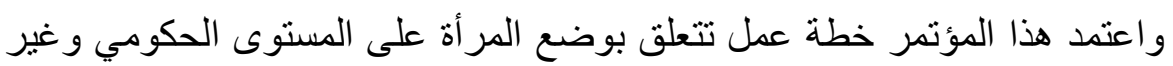

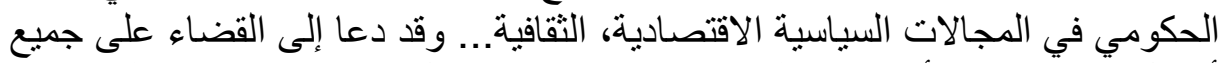

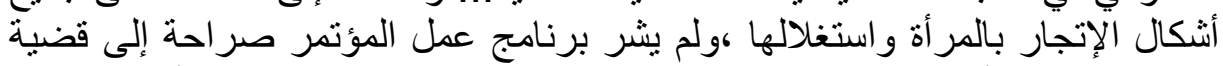

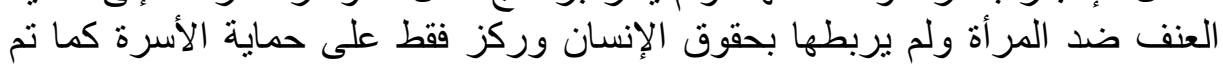

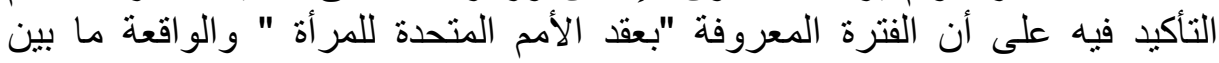
1985-1976 هي فترة لتمكين المرأة من حقوقها التي من بينها الحق في حياة خالية من العنف وذلك من خلال المساو اة والتنمية والسلم (20).

وبعد خمس سنو ات من مؤتمر مكسيكو سيتي عقد مؤتمر كوبنهاجن المنعقد من 14 إلى 30 نموز 1980 طبقا للجمعية العامة رقم 191/33 المؤرخ في 29 كانون مؤن الثناني

(21) 1979

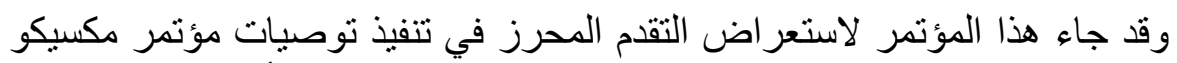

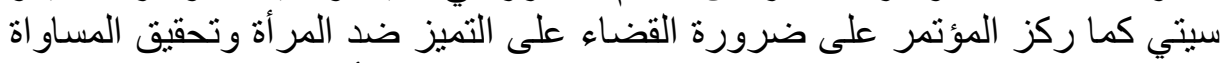

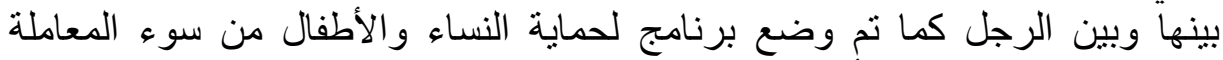
النفسية و الجسدية داخل الأسرة.

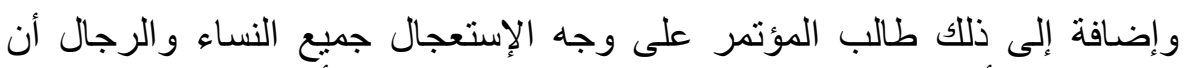

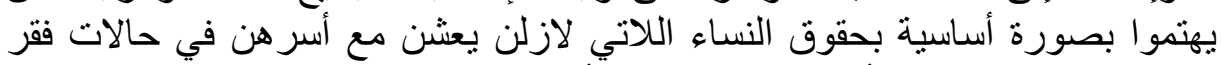

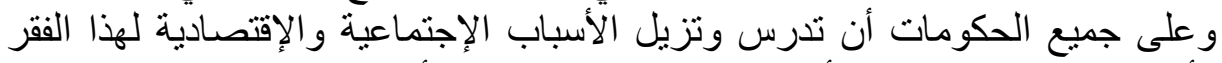

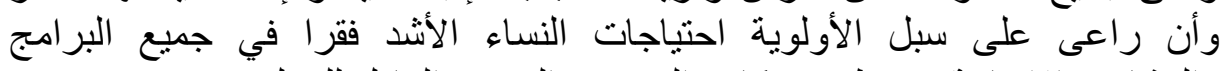

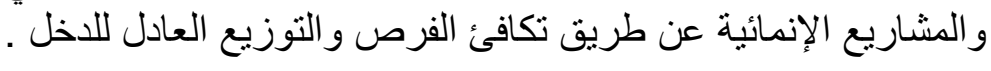

وفي سنة 1985 عقد مؤتمر نيروبي من 15 إلى 26 نموز 1985 طبقا لقرار

الجمعية العامة رقم 136/35 المؤرخ في 11 كانون الأول 1980 (22)

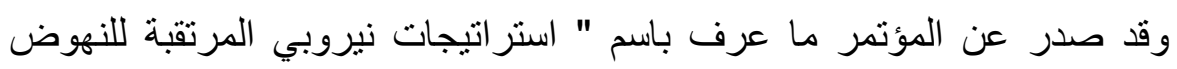

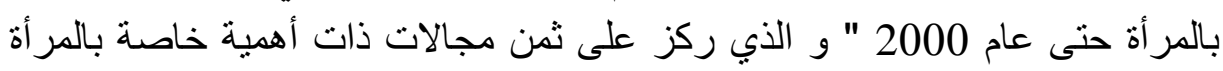

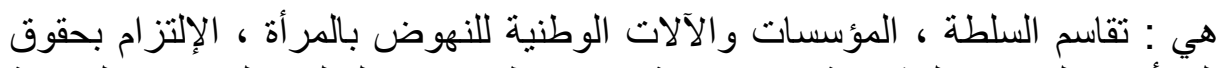

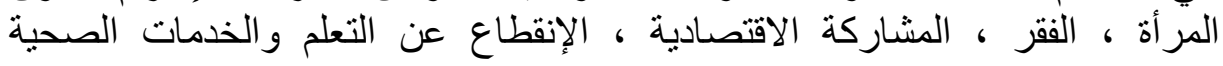
و العمالة ، العنف ضد المرأة ، آثار النزاعات المسلحة على المانة ، المرأة (23).

ومن هنا بدأت تطرح مشكلة العنف ضد المرأة كمشكلة عالمية نظر الانتشار ها

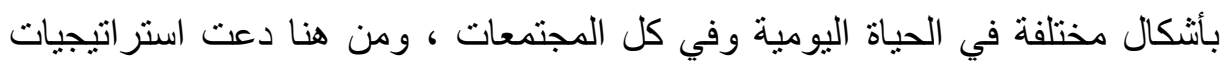

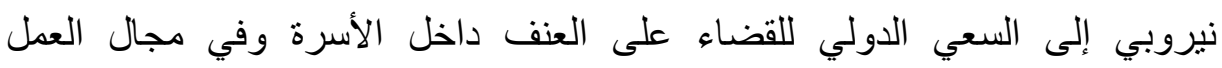


و المجتمع و اتخاذ التدابير الفورية و الر ادعة لمرتكبي العنف ضد المد المرأة .

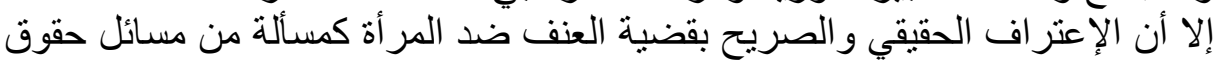

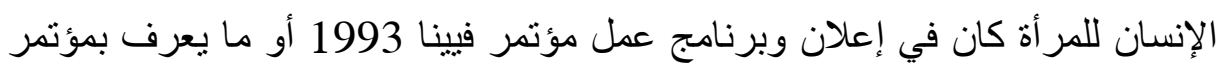
حقوق الإنسان (24).

وقد تضمن نصوصا صريحة في تجريم العنف ضد المر أة ،ققد ورد في البند 18

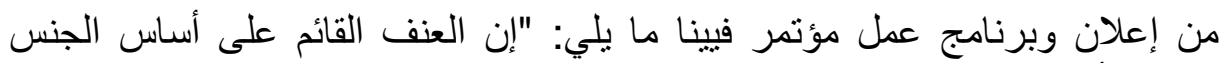

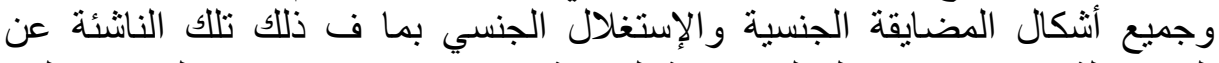

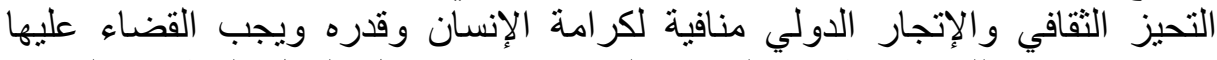

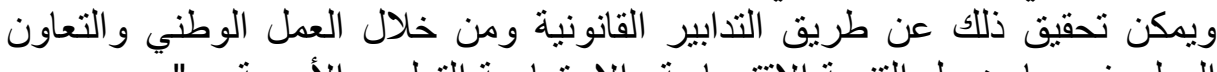
الدولي في ميادين مل التنمية الاقتصادية والاجتماعية التعليم ، الأمومة... "

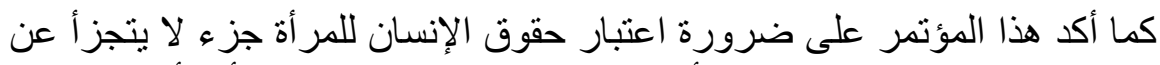

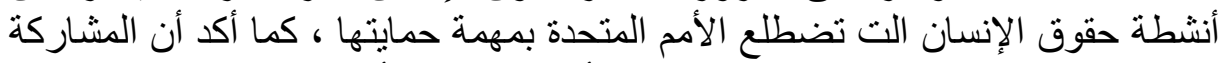

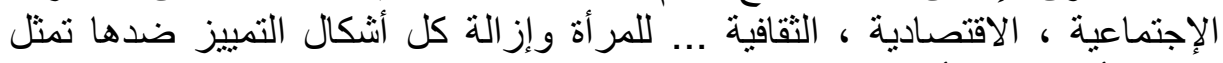

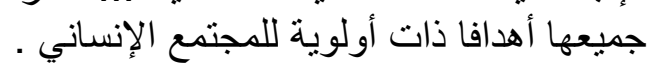

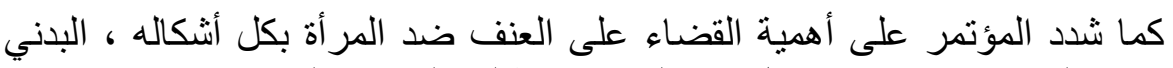

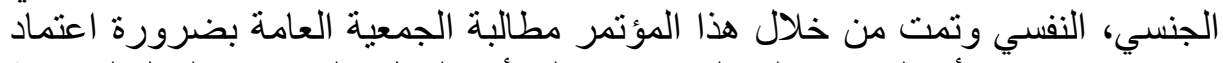

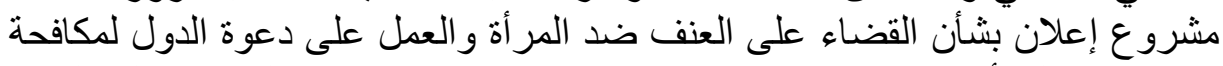

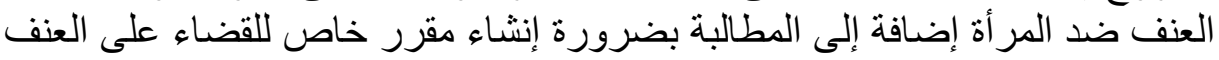

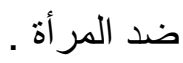
واستكمالا لما جاءت به المؤتمرات الخاصة بقضايا المرأة عقد المؤتمر الدولي

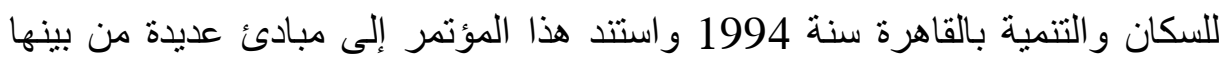

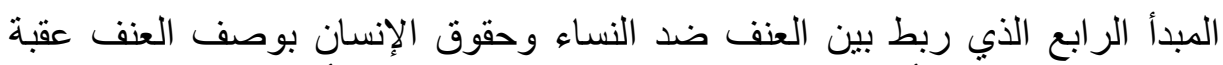
تحول دون تمتع ألمر أة الكامل بحقوق الإنسان القائمة على مبدأ المساو المباة بين الجنسين كهذف يصبو لله مؤتمر القاهرة

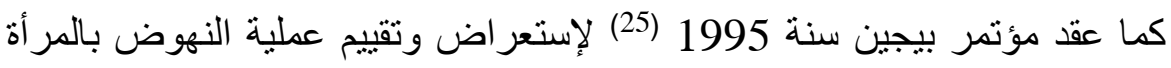

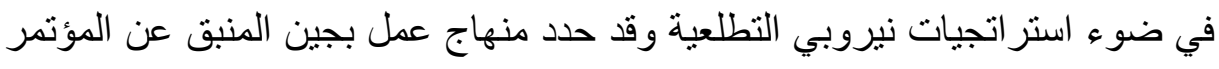

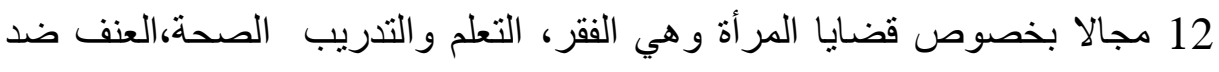

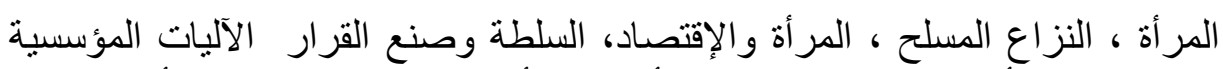

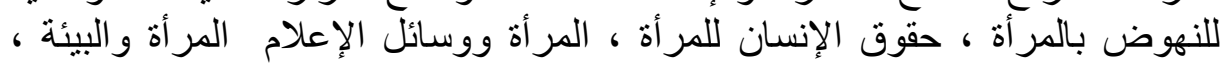

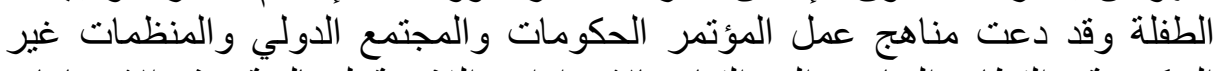

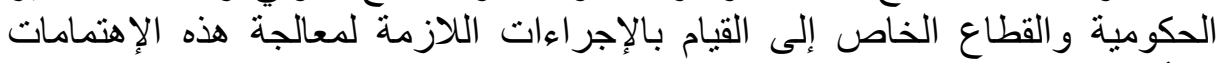

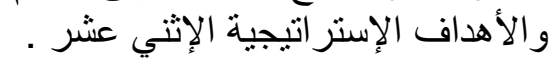

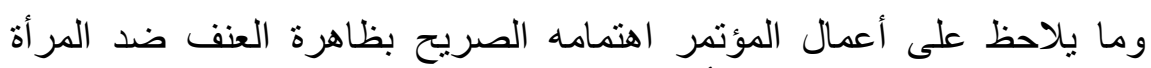

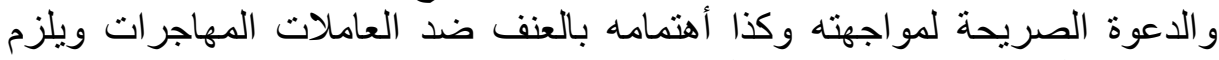

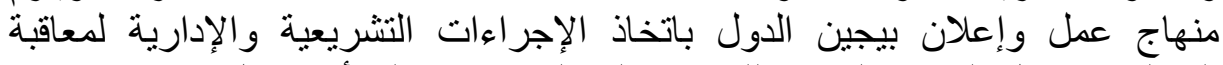

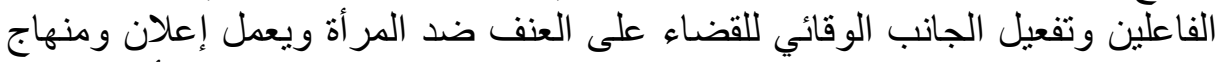

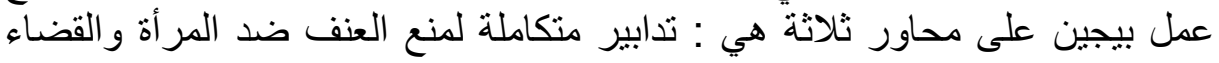


عليه ، ودر اسة أسباب العنف وآثاره وفعالية التدابير الوقائية والقضاء على الإتجار

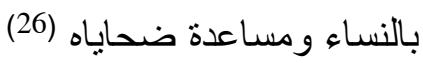

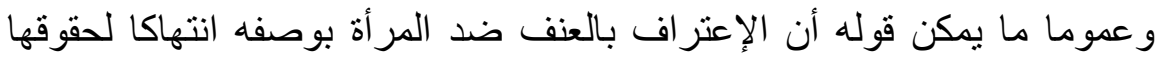

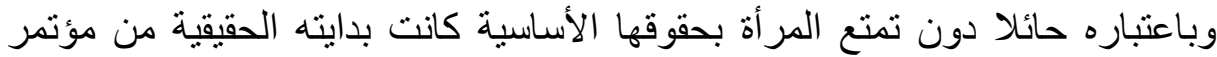

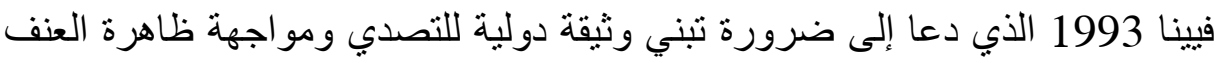

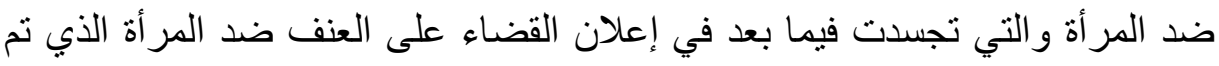
تبنيه من قبل الجمعية العامة عام 1993 ـ

ثالثا : دور الجمعية العامة في إصدار القرارات الدولية

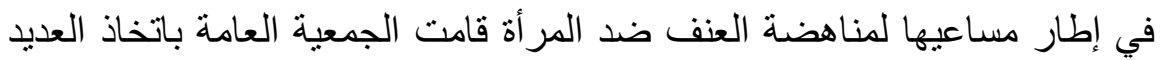

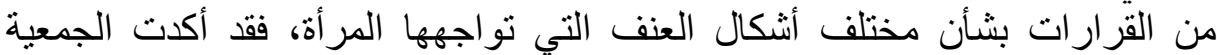

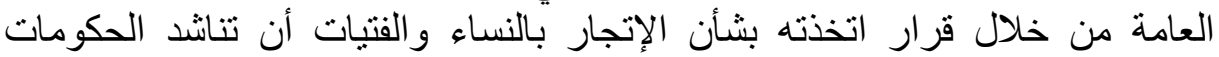

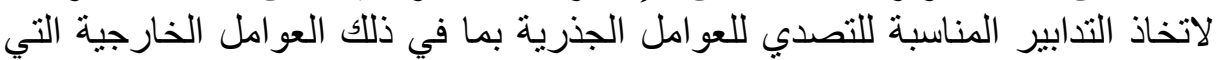

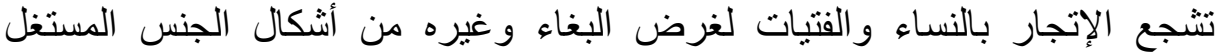

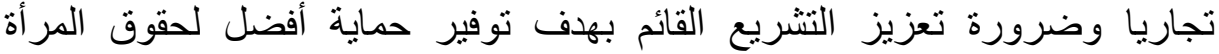

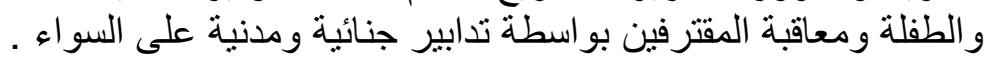

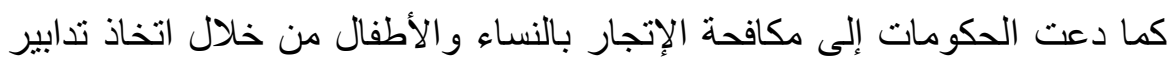

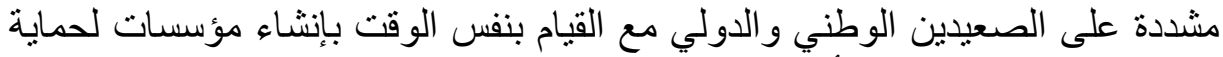

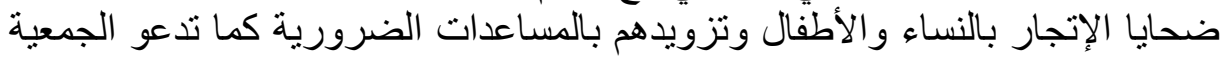

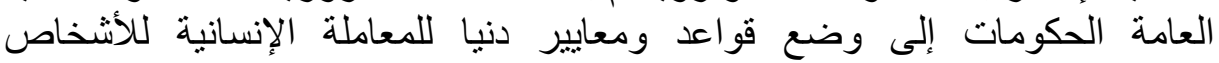
المعرضين للإتجار بحيث تكون متفقة مع معايير حقوق الإنسان (27).

وفي قرار آخر اتخذته الجمعية العامة في دورتها الخمسين أكدت على تثمين ما

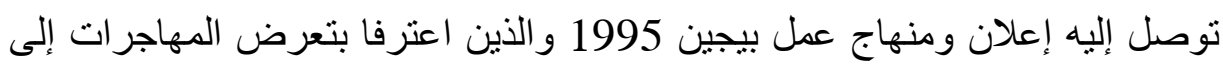

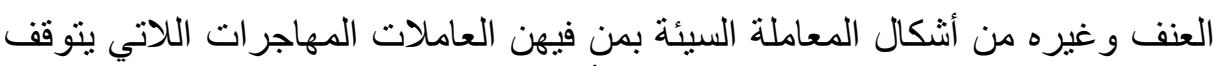

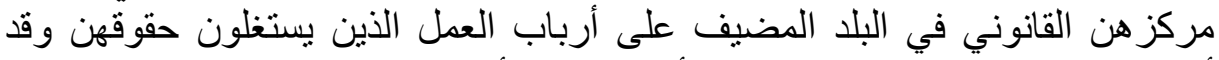

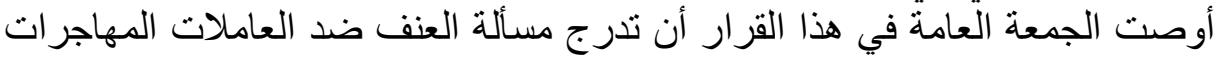

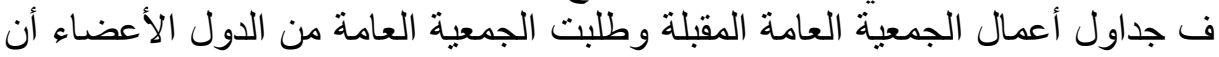

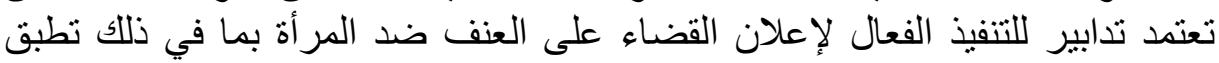

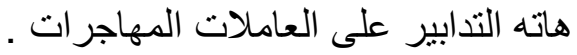

كما تشجع الجمعية العامة بناء على هذا القرار الدول على التى سن الجزاء إتات الجنائية

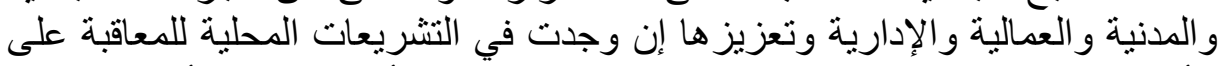

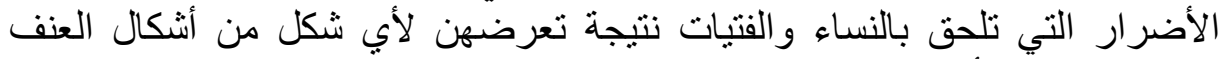

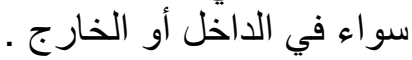

كما أكدت على الدول الأعضاء قيامها وبخاصة الدول المرسلة والدولة المستقبلة

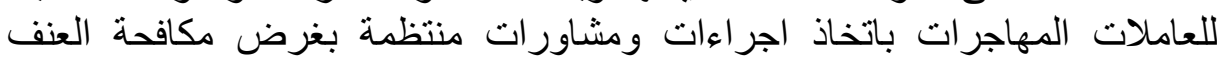

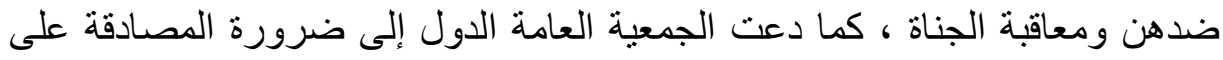
الإتفاقية الدولية لحماية جميع العمال المهاجرين وأسر هم (28). وفي قرار آخر اتخذته الجمعية العامة في دورتها 52 حثت الدول على رسم سياسة نشطة ومحسوسة ترمي إلى إدراج نوع الجنس في صياغة البرامج امج وتنفيذها في ميدان منع الجريمة والعدالة الجنائية التي قد تساعد في القضاء على التى العنف ضد المر أة كما 


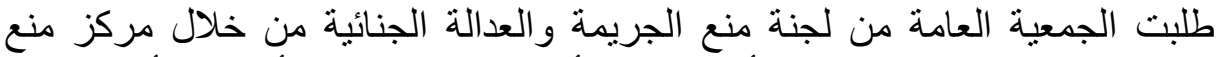

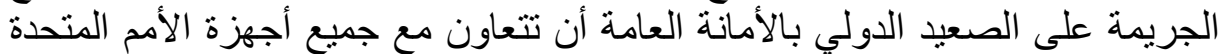

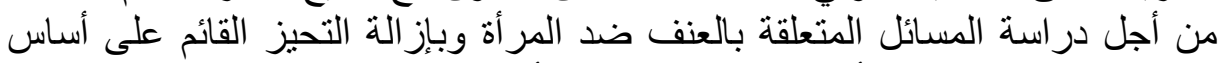

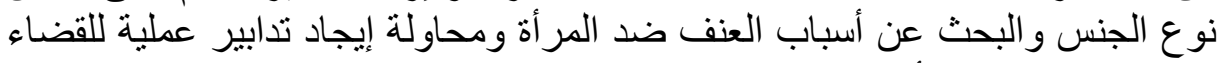
على العنف ضد الجن المر أة .

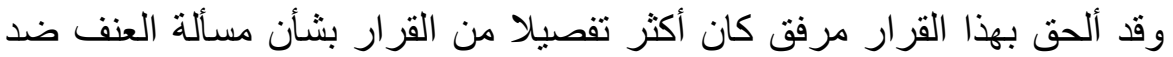

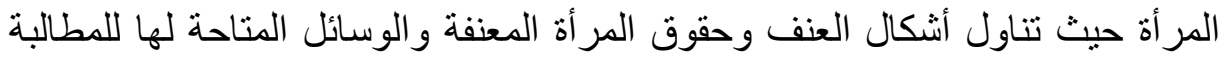

بالتعويض عن الأضر ار التي تلحق بها جراء العنف التف (29)

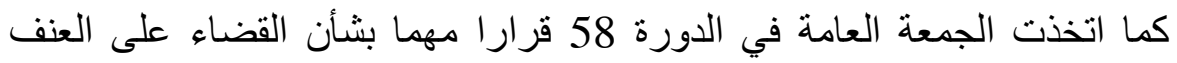

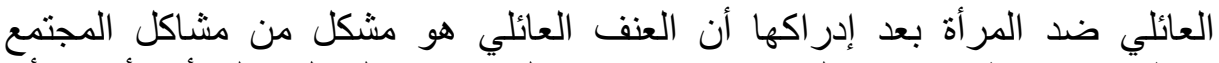

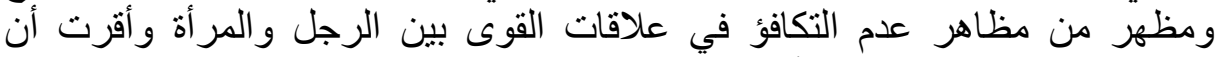

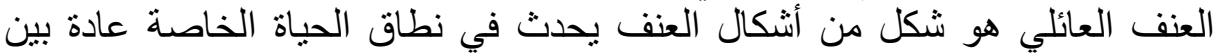

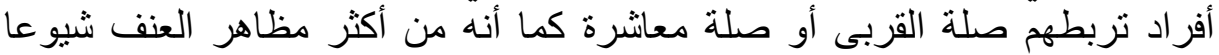

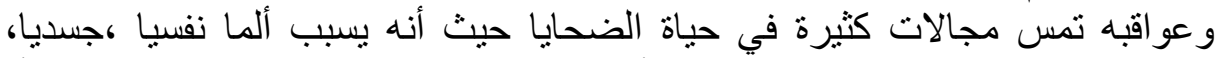
جنسيا ...وتدين الجمعية العامة بشدة أنثكال العنف العائلي الممارس على الثى المرأة و الطفلة .

وأكدت على الدول ضرورة اتخاذ التدابير اللازمة كالتدابير العقابية واعتبار العنف

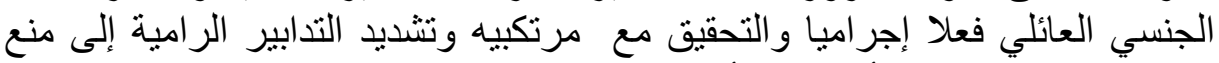

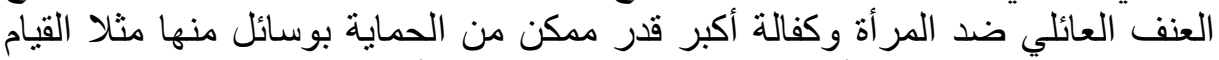

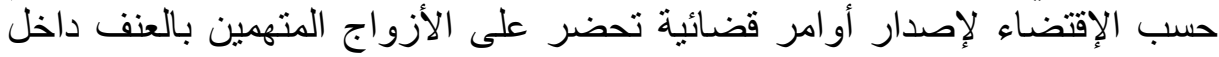

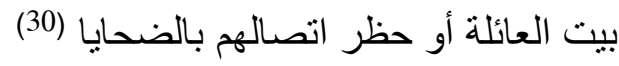

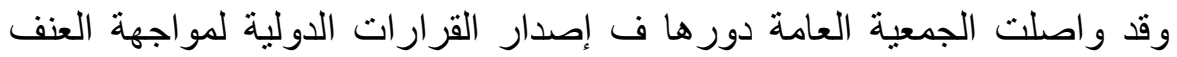

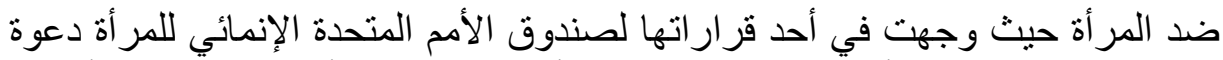

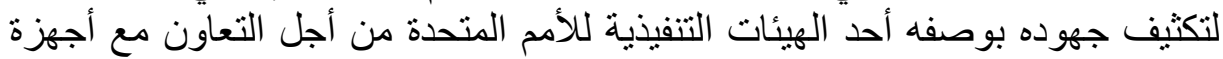

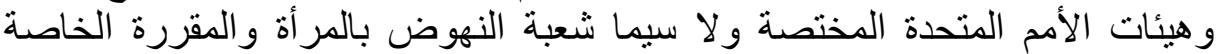

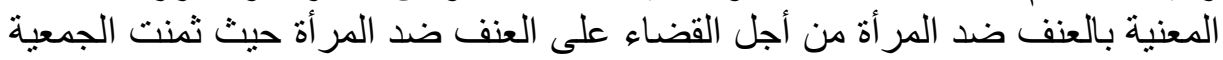

العامة في قرار ها جهود الصندوق في هذا المجال (31).

و استكمالا لمساعيها لمناهضة العنف ضد المرأة قررت الجمعية العامة بموجب

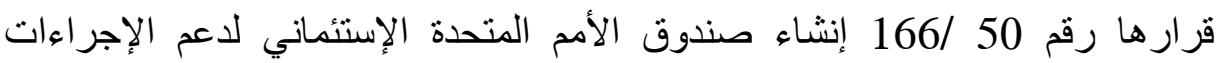
الرامية إلى القضاء على العنف ضد المرأة وذلك عام 1996 وهو عبارة عن آلية

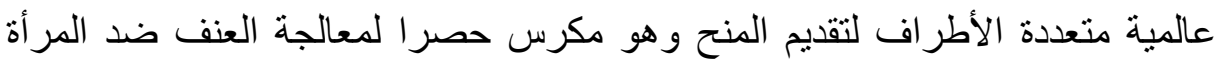

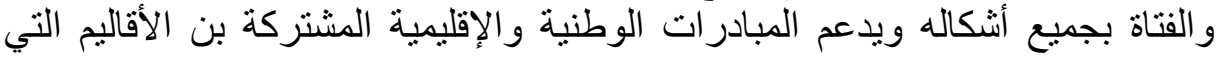

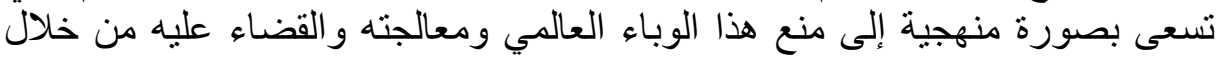

المثابرة (32).

كما طلبت الجمعية العامة للأمم المتحدة بموجب قرارها رقم 165/58 من الأمين

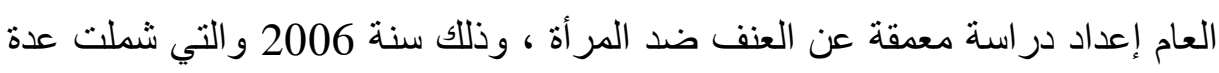

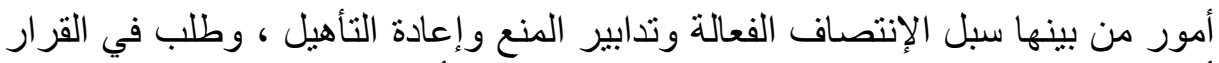

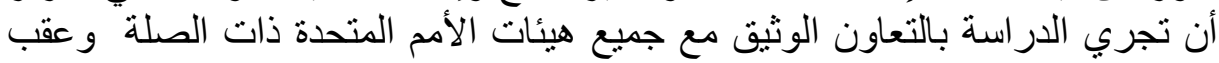


هذه الدراسة اتخذت الجمعية العامة القرار رقم 143/61 المؤرخ في 19 ديسمبر 2006 و المتعلق بتكثيف جهود القضاء على العنف الموجه ضد المر أة وطلبت الجمعية العامة من الأمين العام إصدار تقرير سنوي عن تنفيذ هذا القرار ، كما حثت الجمعية العامة كيانات الأمم المتحدة على تنسيق جهودها الماند لمو اجهة العنف (33).

وفي عام 2007 كان موضوع اليوم الدولي للمرأة هو" وضع حد للإفلات من العقاب لمرتكبي العنف ضد النساء والفتيات" و أطلق السيد" بانكي مون" في يوم 25 شباط 2008 حملة الأمين العام العالمية اتخذت لإنهاء العنف ضد المرأة واصفا الوضع بالقضية التي لا يمكن تأخير ها(34). و وتثمينا منها لمكانة المر أة و الرفع من قيمتها ومكافحة العنف ضدها اعتبرت الأمم المتحدة بقرار من الجمعية العامة يوم 25 نوفمبر من كل سنة يوما عالميا لمكافحة العنف ضد المر أة (35).

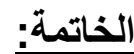

إن قضية العنف ضد المرأة من القضايا الهامة التي ذاع صنها على الصعيد العالمي والوطني فلا يجوز إغفالها أو التهاون بها الأمر الذي يتطلب تفعيل كل الجهود

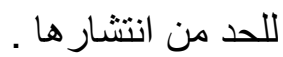

كما أن العنف ليس سوى آلة لهدم طاقات المر أة العطاءة ومو اهبها التي قدر لها أن

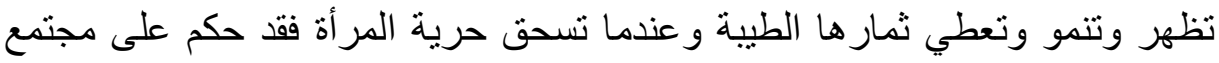

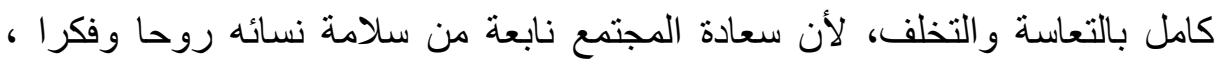
وكلما تحررت المر أة من الضغوط التي يصطنعها الجنس الآخر لإضطهادها لإنها كلما سار

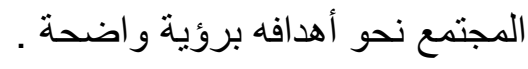

وبالرغم من أن هنالك جهودا دولية لحماية المرأة من العنف تحمل في طياتها اتفاقيات وإعلانات دولة والتي كانت على رأسها إتفاقية سيداو والتي لقيت أكبر التهر

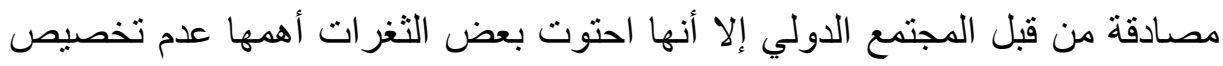

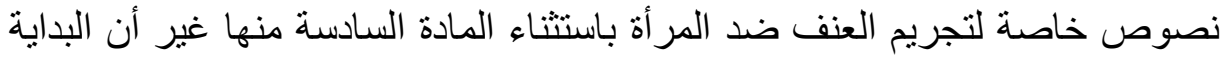

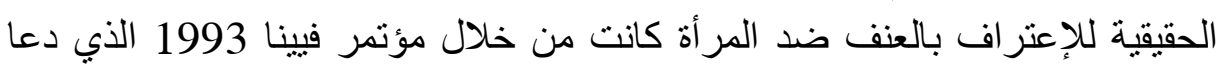
بصورة صريحة إلى ضرورة تبني وثثقة دولية تجرم العنف ضد المرأة فاستجابت

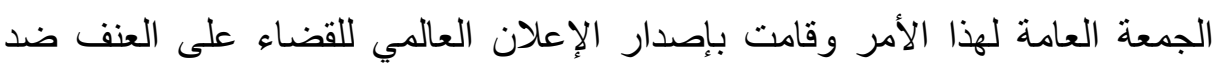

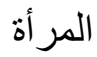

غير أن جهود الجمعية العامة في إبرامها لإتفاقية سيداو هو إصدارها للإعلان

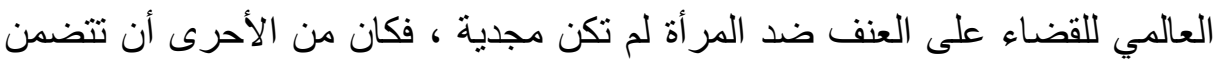

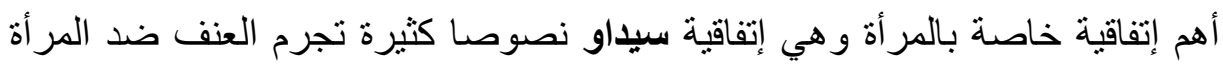
كما أنها لم تتضمن و لا نص واحد صريح حول العنف ضد المر أة . 
ضف إلى ذللك كان من الأجدر أن تصدر الجمعية العامة باتفاق الدول إتفاقية دولية للقضاء على العنف ضد المرأة بدلا من إعلان لأنه لا يحوز نفس القوة الإنه الإلزامية للإتفاقية .

أما بالنسبة للقرارات التي أصدرتها الجمعية العامة والمشار إليها سابقا والمتعلقة

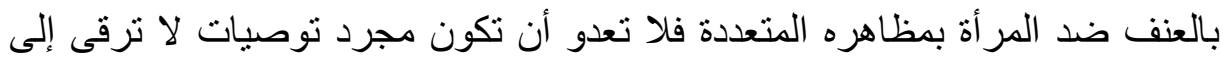

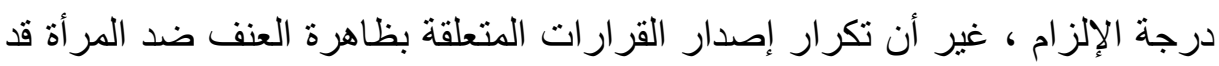

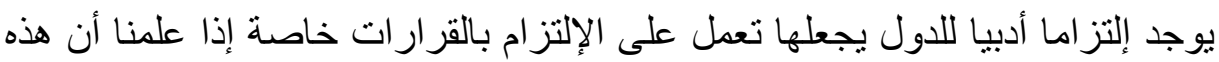

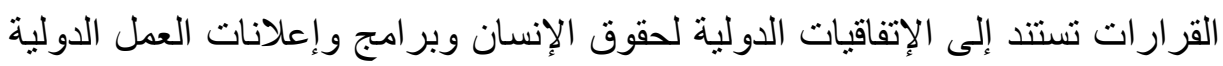

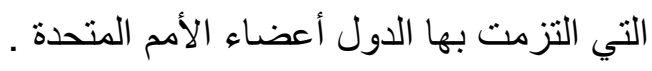

لذا نرى أن مشكلة العنف ضد المرأة في البحث عن حلول لها يتوجب معالجتها من

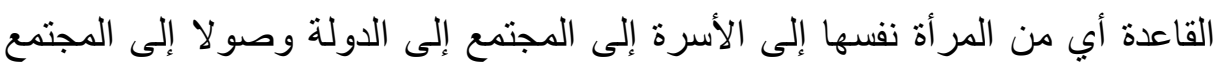

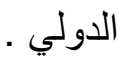

و على الرغم من أن سلطة الجمعية العامة تقتصر على إصدار توصيات غير ملزمة

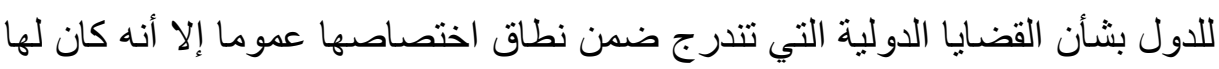

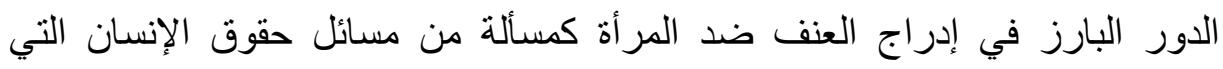
تستوجب الوقوف عندها ، ومع ذلك يتوجب إعادة النظر في هاته الظاهرة وذللك:

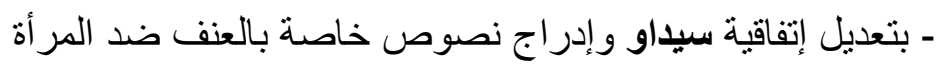

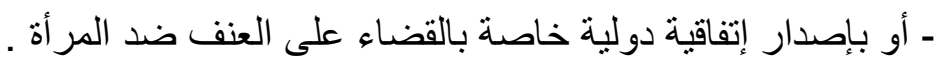

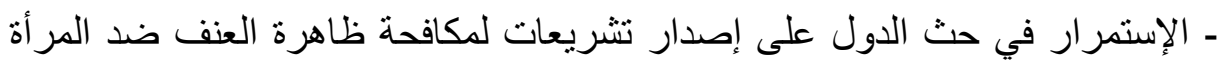
أو تعديل التشريعات الموجودة و عدم تقاعسها في ذلك التول ..

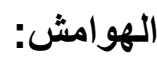
(1) أنيس ابراهيم، عطية الصوالحي وآخرون، الدعجم الوسيط، ج2، مجمع اللغة العربية، القاهرة، د

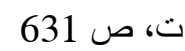
(202) أزهار صبيح عنتاب، العنف في الصحافة العربية الدولية، دار أسامة للنشر والتوزيع، الأردن، 2011، صن صن 10 (03) سميحة نصر، العنف و المشقة، المركز القومي للبحوث الاجتماعية والجنائية القاهرة، 1996، ص

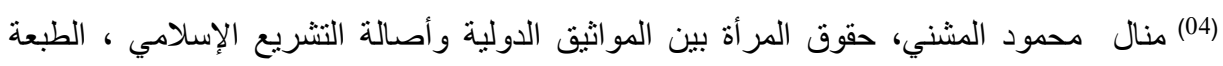

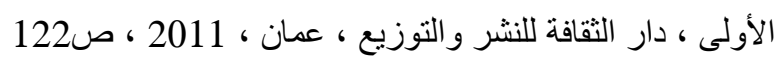
(05) أحمد بنيني، الحماية الدولية والوطنية للمرأة من العنف ،مجلة العلوم الإنسانية العدد 32 ، جامعة

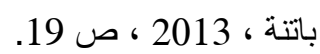
(06) بكير بن حمودة حاج سعيد، الأطفال والعنف-أصله، منابعه، أسبابه، وطرق علاجه-، دار

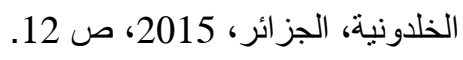
(07) بكير بن حمودة حاج سعيد، المرجع نفسه، ص12 
(08) المادة الأولى من إعلان بشأن القضاء على العنف ضد المر أة الذي اعتمدته الجمعية العامة بموجب قرار ها 104/48 المؤرخ في 20 ديسمبر 1993 ، موقع المفوضية السامية لحقوق الإنسان . http://www.ohchr:org/ AR/Professionallnterest/Pages/Violence Against Women .aspx.

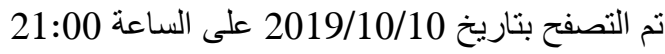
(09) الاتفاقية الأمريكية بشأن منع واستئصال العنف ضد النساء والعقاب عليه ، مكتبة حقوق الإنسان،

http://hrlibrary.umn.edu/arab/am6.html

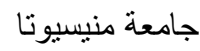

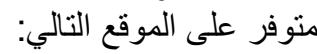
تم التصفح بتاريخ 2019/10/08 على الساعة 15:00 (10)عالية أحمد صالح ضيف الله ، العنف ضد المرأة بين الفقه والمواثيق الدولية الطبعة الأولى، دار

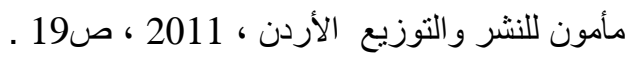
(11) نهى القاطرجي ، المر أة في منظومة الأمم المتحدة - رؤية إسلامية ـ الطبعة الأولى ، مجد للنشر و التوزيع ، لبنان 2006 ص ص 373 21 (12) عالية أحمد صالح ضيف الله، المرجع السابق، صله صله (13)محمود عبد الغني ، حقوق المرأة في القانون الدولي العام والشريعة الإسلامية الطبعة الأولى ،

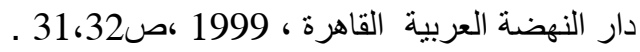
(14) محمود عبد الغني، المرجع نفسه، ص 43 (15) الفقرة 6 من التوصية رقم 19، العنف ضد المرأة، لجنة القضاء على التمييز ضد المرأة، الدورة 1992،11، موقع مكتبة حقوق الإنسان، جامعة مينيسيوتا متوفر على الموقع: http: // www1.umns edu/ humanrts/ arabic/ cedawr19. Html.

تم التصفح بتاريخ 2019/10/11 على الساعة 20:00 (16) الفقرة 7، التوصية رقم 19، العنف ضد المرأة، لجنة القضاء على التمبيز ضد المرأة، المرجع

(17) هالة سعيد تبسي، حقوق المرأة في ظل إتفاقية القضاء على كافة أثكال التمبيز ضد المرأة (أنس سيداو) ، الطبعة الأولى منشورات الحلبي الحقوقية ، بيروت ، 2011 ص391. (18)علوان محمد يوسف ، محمد خليل الموسى، القانون الدولي لحقوق الإنسان ـالمصادر ووسائل الرقابة ـالجزء الأول الطبعة الأولى ، دار الثقافة للنشر والتوزيع عمان ، 2005 ، ص514 (19) كلوديو زانغي ، ترجمة محمد بجاوي ، الحماية الدولية لحقوق الإنسان ، الطبعة الأولى ، مكتبة

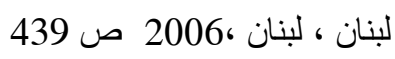

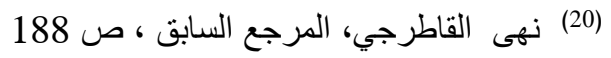
(21) علوان عبد الكريم ، الوسيط في القانون الدولي العام - حقوق الإنسان - الكتاب الثالث ، دار

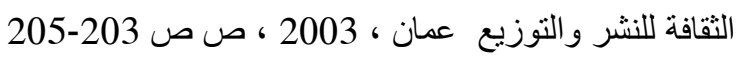

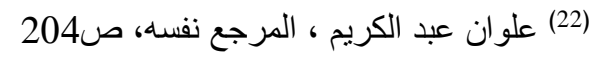
(23) نهى القاطرجي، المرجع السابق ، ص صع $192(24)$

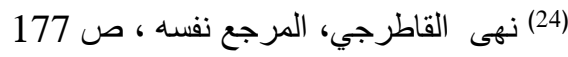

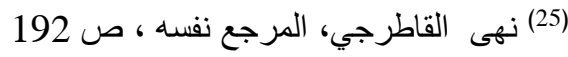

(26) هيفاء أبو غزالة ، الإستراتيجية العربية لمناهضة العنف ضد المرأة ( 2011-2020)، الطبعة الأولى ، منظمة المر أة العربية ، القاهرة ، 2011، صله 
(27) قرار إنخذته الجمعية العامة في الدورة 50 ، البند 107 من جدول الأعمال رمز الوثيقة A/RES/50/167 بتاريخ 16 فيفري 1996 والخاص بالإتجار بالنساء متوفر على الموقع : www.un.org/arabic/docs/viewdoc.asp ؟docnumber=A/RES/50/167

تاريخ التصفح 18 فيفري 2019 على الساعة

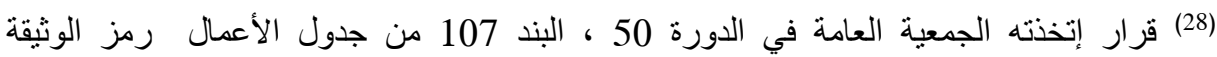
A/RES/50/168 بتاريخ 16 فيفري 1996 والخاص بمكافحة العنف ضد المهاجرات العاملات www.un.org/arabic/docs/viewdoc.asp ؟docnumber=A/RES/50/168

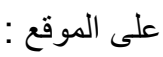
تاريخ التصفح 18 فيفري 2019 على الساعة

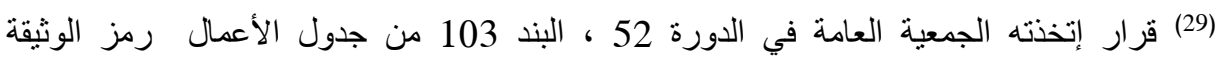

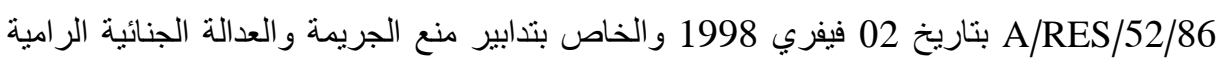
إلى القضاء على العنف ضدارئ المرأة على الموقع:

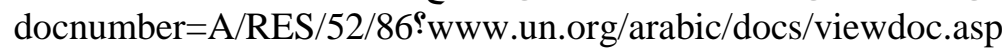
تاريخ التصفح /04/12/ 18:40 2019 على الساعة

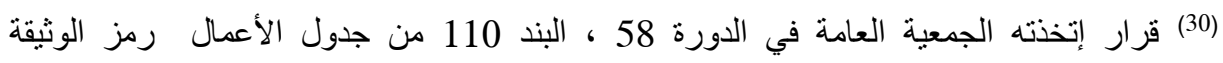

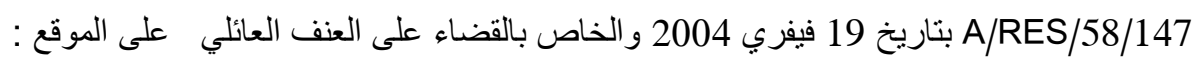
www.un.org/arabic/docs/viewdoc.asp? docnumber=A/RES/58/147

تاريخ التصفح 12 /04/ 2019 على الساعة 18:47 (31) قرار إتخذته الجمعية العامة في الدورة 50 ، البند 107 من جدول الأعمال رمز راعة الوثيقة

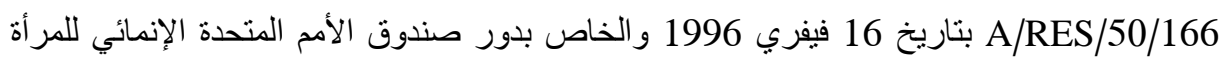
في القضاء على العنف ضد المر أة على الموقع : www.un.org/arabic/docs/viewdoc.a؟ docnumber=A/RES/50/166

تاريخ التصفح 05/14 /2019 على الساعة 18:40

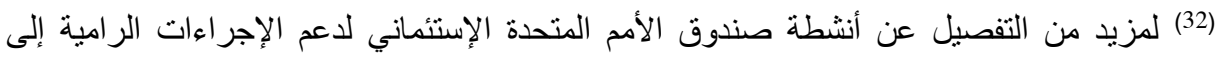

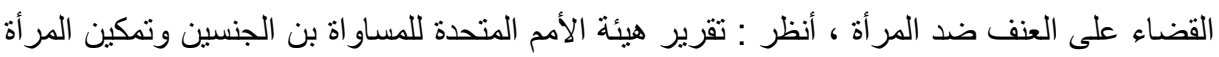
www.ohchr.org>A H_C_26_3_ARA

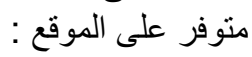
(33) بن عطا الله بن علية، الآليات القانونية لككافحة العنف ضد المرأة، مذكرة مقدمة لنيل شهادة الماجستير في الحقوق تخصص حقوق الإنسان والحريات العامة ، جامعة قاصدي مرباح، كلية

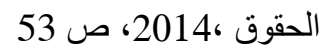
(34) رندة الفخري عون، التمييز ضد المرأة في ضوء أبرز المواثيق الدولية-دراسة مقارنة-، منشورات زين الحقوقية ، بيروت

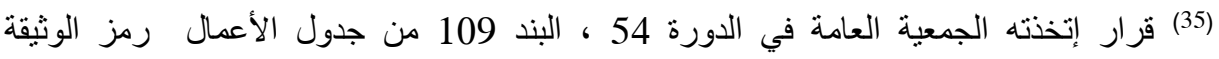
A/RES/54/134 بتاريخ 07 فيفري 2000 و الخاص باعتبار يوم 25 نوفمبر يوما عالميا لدكافحة www.un.org/arabic/docs/viewdoc.asp ؟docnumber=A/RES/54/134 العنف ضد المرأة على الموقع : تاريخ التصفح 18 فيفري 2017 على الساعة 18:40 